These reviews are available open access under a CC BY 4.0 license as part of Berghahn Open Anthro, a subscribe-to-open model for APC-free open access made possible by the journal's subscribers.

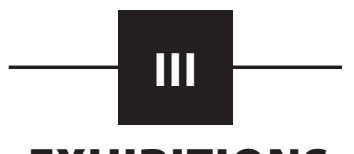

EXHIBITIONS

\title{
EXHIBITION REVIEW ESSAYS
}

\section{The Museum of Removals in Vila Autódromo, Rio de Janeiro}

The story of the Museum of Removals (Museu das Remoções), in Vila Autódromo, Rio de Janeiro, is told from the ground up. Located in the middle of a remodeled part of the city, in the West zone of Rio, the open territory with few houses invites us to look down instead of looking up to monumental buildings and showcases, as in any "classical" museum. The museum has no walls, except for those that separate this surviving urban community of Vila Autódromo from the gentrified city that continues to expand and advance to its peripheries (see Figure 1). While walking through the space of its land-based exhibition, it is in the fragments on the ground, the remains of an urban community of over seven hundred families left to attest to their absence, where our experience of this striking museum starts.

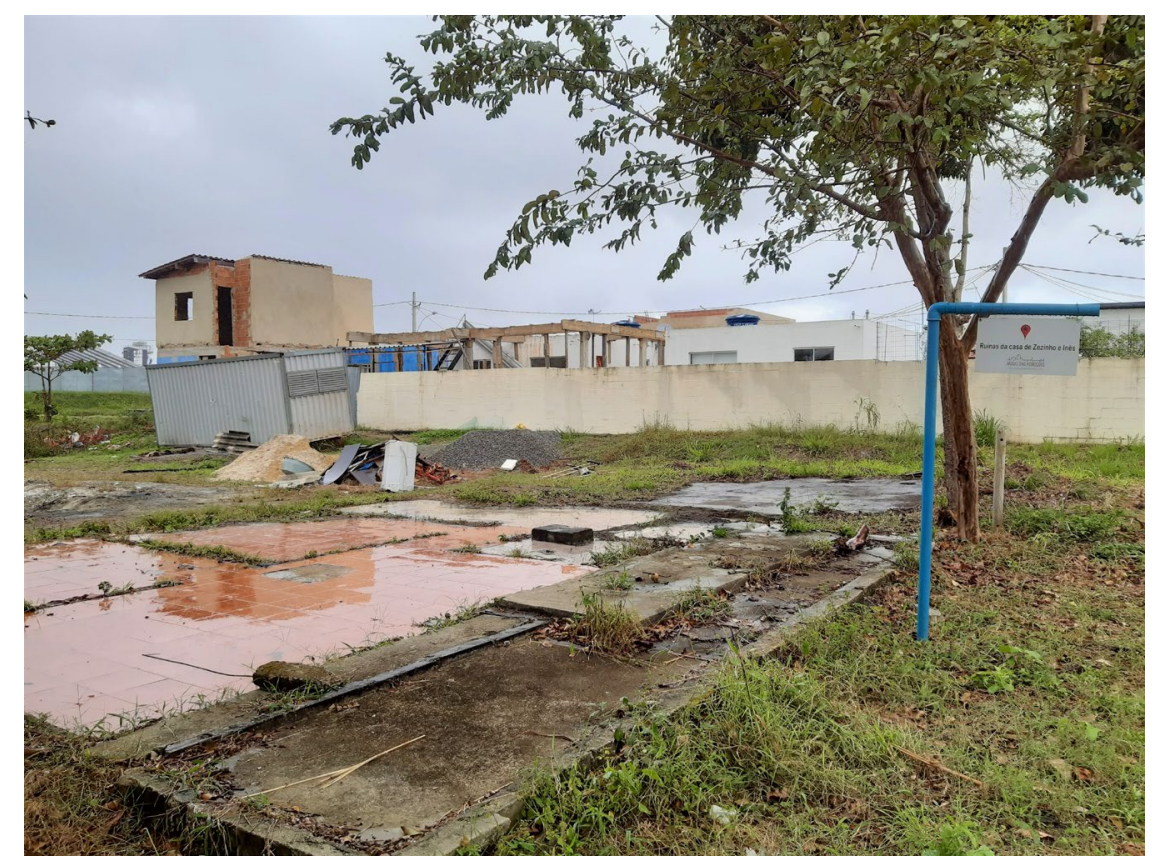

Figure 1. Museu das Remoções, Vila Autódromo, Rio de Janeiro. Exhibition path, 2019. Courtesy of the Laboratory of Experimental Museology at the Federal University of the State of Rio de Janeiro, UNIRIO. 
The Museum of Removals was inaugurated in May 2016, as a "territorial" museum based on the ideas of "social museology," with the purpose of denouncing state action against vulnerable communities in the peripheries of the city by evoking the brutal story of removals and state violence against those to whom Vila Autódromo was a home and a peaceful place to live. With a strong history of community-based museums in Brazil, this museum was born and flourished as a claim for the right to the city, and has been guiding cultural activism in Vila Autódromo since its first artistic event in 2015-the Festival Cultural \#OcupaVilaAutódromo, organized by community members, collaborators, and activists in August that year.

The removals in Vila Autódromo, which took place between 2014 and 2016 and which were carried out in a systematic and oppressive way by the Rio de Janeiro prefecture, were part of a project for "urban renewal" motivated by the 2016 Olympic and Paralympic Games, in the midst of which an urban reform program was put into practice (see Figure 2). Such a reformulation, embedded in the discourse of "renewal" and development of the city, mainly served the business interests and the dynamics of the neoliberal market, and has been denounced by critics. ${ }^{2}$ As a result of the struggle for the right to dwellings, and the daily confrontation with the government, the Vila (village), as it is usually called by its residents and activists, has been drastically transformed from an area inhabited by more than seven hundred families into a space in ruins, marked by the loss of its most immediate heritage-people's houses, their living spaces, the square where children played, the domestic animals, the wooded landscape, meeting places, and the marks of a lived history on the land.

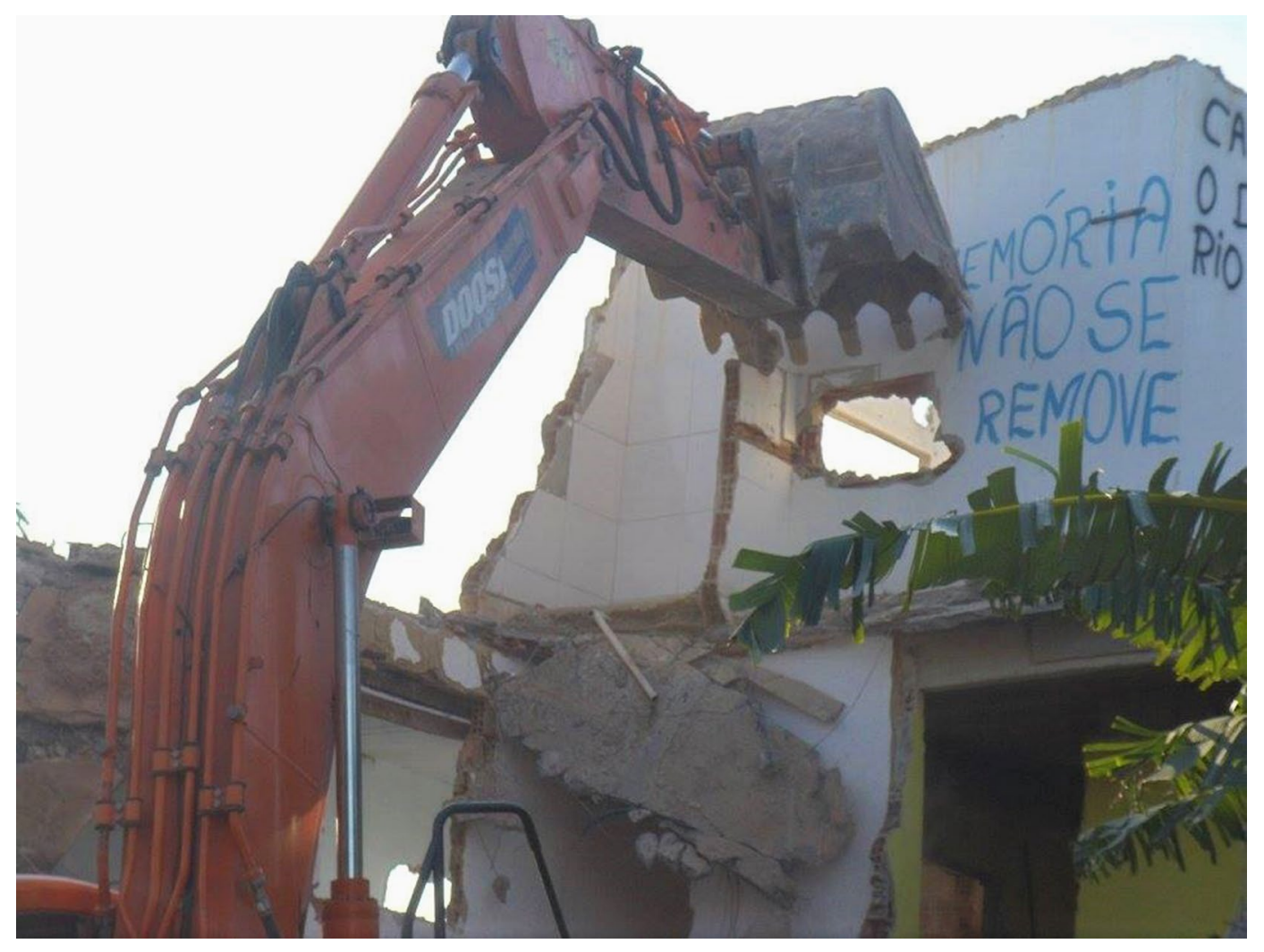

Figure 2. "Memories cannot be removed." Photograph of Vila Autódromo, Rio de Janeiro, 2016, by Luiz Claudio Silva. Courtesy of Museu das Remoções. 
In reaction to the deliberate destruction of this community, with little chance to bargain, and facing the use of unfair methods from the public authority, a museum was born from the resistance. This museum, still struggling to survive as a device for contestation, is the result of organized action that revalues the remains of the community left on the site, as an activist gesture by the inhabitants that still fight to stay and live in Vila Autódromo. Their right to memory is here inseparable from the right to housing, and the museum allows their cause to be spread to other favelas and marginal communities endangered with elimination from the city map. Their fight is a deliberate attempt to defy public power by making visible a "human geography of social contact," as David Harvey proposes (one of the scholars who was present in Vila Autódromo to support the community cause during the period of removals). ${ }^{3}$

The exhibition path inaugurated on 23 September 2018, the museum's only long-term exhibition, was created by local inhabitants and collaborators through the selection of sensitive points marked by sculptures in the old area of the community, and which was based on the work of collective memory and oral history involving former residents of Vila Autódromo. The museum organized an event, a reunion of community members removed from their land, to recognize such elements of remembrance among the ruins of their homes, backyards, and streets, which were no longer identifiable to the eyes of any outsider. From this work, an exhibition was created with twenty-four simple plaques indicating eighteen sites of memory as references for the community. Four of them refer to the main streets where the residents fought municipal guards and state workers in resistance against the removal of their homes. In addition, twenty-one other plaques refer to structures that can no longer be seen, but only imagined from the ruins and paving still present on the ground, like the roots of a shattered tree from the past that insists on being seen in order to be remembered: for example, the home of Zezinho and Inês, the home of Wilson and Iolanda, the post in front of Jaqueline's house, the resident's association, the old bakery, the children's park, the main street Vila Autódromo, and the last barricades.

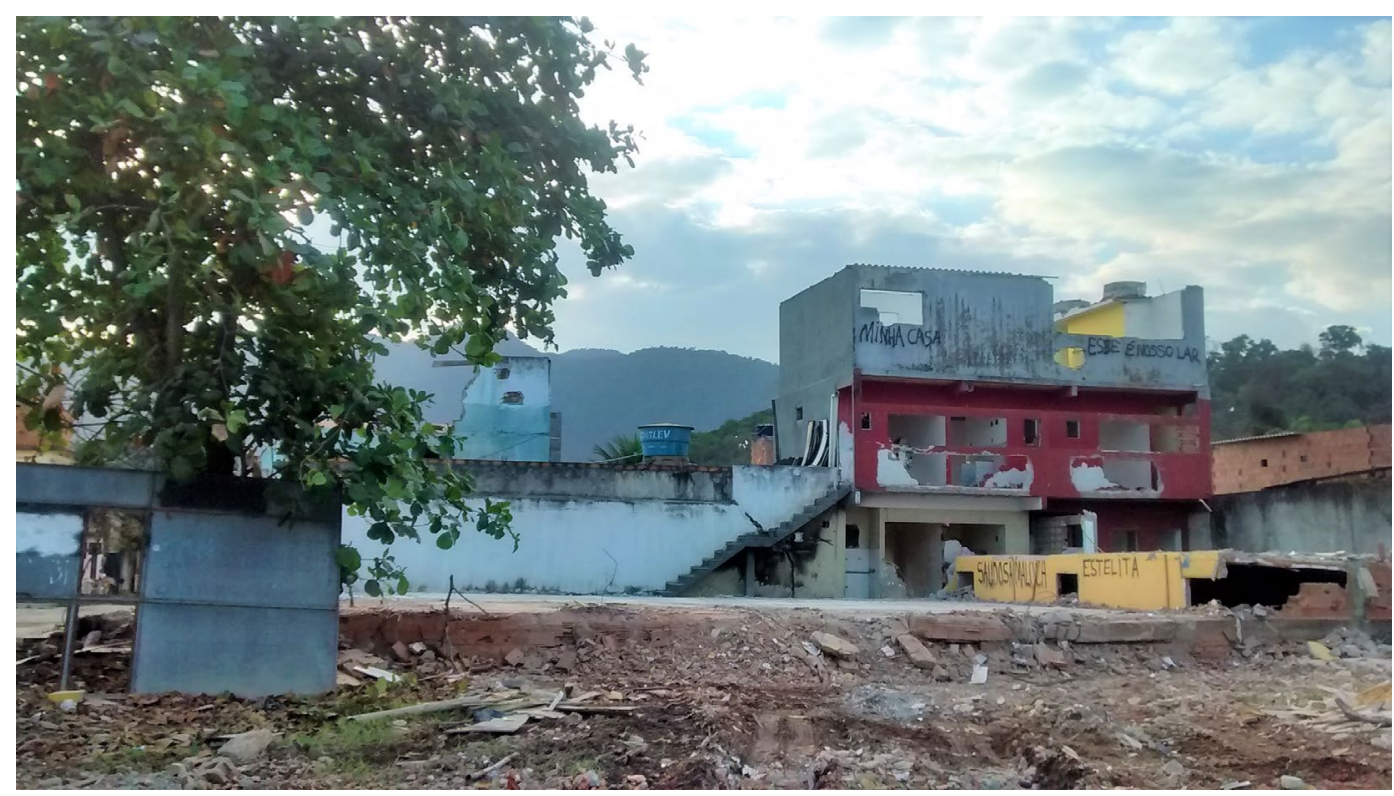

Figure 3. The space for the Festival Cultural \#OcupaVilaAutódromo, August 2015. Photo by Luiz Claudio Silva. Courtesy of Museu das Remoções. 
All the material used in the exhibition tells a story about the removals. Plaques and signs were made from the rubbish scraps found on the ground. New meaning is given to materials from the devastated community through the museum's restorative narrative, regenerating the memories and the lives of those who are connected to them. The museum motto, "memories cannot be removed," is an inspirational affirmation that allows the remaining inhabitants to give purpose to their resistance.

Each spot in the exhibition path is an opportunity for the visitor to be told the personal and collective stories that remain from the destroyed neighborhood. On my first visit to the museum exhibition, I was welcomed by Luiz Claudio Silva, a physical education teacher who has lived in Vila Autódromo since 1994. During our walk around the ruins, he explained that those sites are only a part of the land that could be preserved. On the other side of both roads that surround the Vila, where we can see a major hotel that is part of an international chain, the expanded city does not allow residents to remember anything. But from that point on, the story of the fight against municipal guards and state agents is brought to the fore. Luiz lost his home, his wife was physically assaulted, and he even lost his job in the process of resistance. Today, his reconstructed house, among the few remaining on the land, is a testimony to a story of activism and survival that is worth telling. His memories and emotions, among those of his neighbors, are the content of this museum.

Luiz guided our group along a path made from empty spaces left by buildings demolished during the removals (see Figure 3), a tour that reinserts Vila Autódromo in a narrative of resistance. Engaged in his testimony as a survivor in the locality, we see no absence, but the fragments preserved in time and re-activated by the memory of other former residents. Each ruin is an opportunity to go back to the history of the resistance and even further to the life of the Vila before the removals, a dislocation in time that is achieved thanks to the methodologies of oral history and the systematic production of photographs-documenting life from before the removals to the present activities of the museum. The points considered "important" along the route (see Figure 4) were pointed out by residents and former residents who participated in the recognition of memories present in the ruins that were left on purpose after the destruction of over ninety-five percent of the integral urban community. Today, only twenty families remain in their reconstructed houses in the destroyed suburb-but this is considered a major achievement by the resistance. Other former residents, now living in other parts of the city, periodically come back to the area, having the museum as a base for their memories to be preserved and shared within the community.

The exhibition route serves the purpose of enabling the remaining inhabitants to tell their stories as part of a movement of resistance that aims to fix their lives in the land and secure their place in the city geography. While they tell their personal stories based on memories from the past, the ruins serve as "proof" of a historical community that can otherwise only be imagined thanks to the museum's rich collection of photographs that are shown to visitors projected on the walls of the community church-the only original building preserved after the removals. At the same time that the museum recreates an imagined Vila Autódromo from previous years, it also reveals the power of the inhabitants' resistance and the various dimensions of their struggle for the right to remain in a place that was rightly granted to them by the state in the 1990s. Positioning themselves as "museum objects" and witnesses of a tragic history, these women and men are constantly affirming their existence as part of a neglected and fractured episode in the urban history of Rio de Janeiro. After visiting the Museu das Remoções and exploring the area a few times, I can attest to the fact that each visit offers a unique experience. Guiding the visitors through the narrative of a removed community, each of the local inhabitants tells their own story and recreates the Vila in their emotional and political enunciations. Their role as narrators is to 


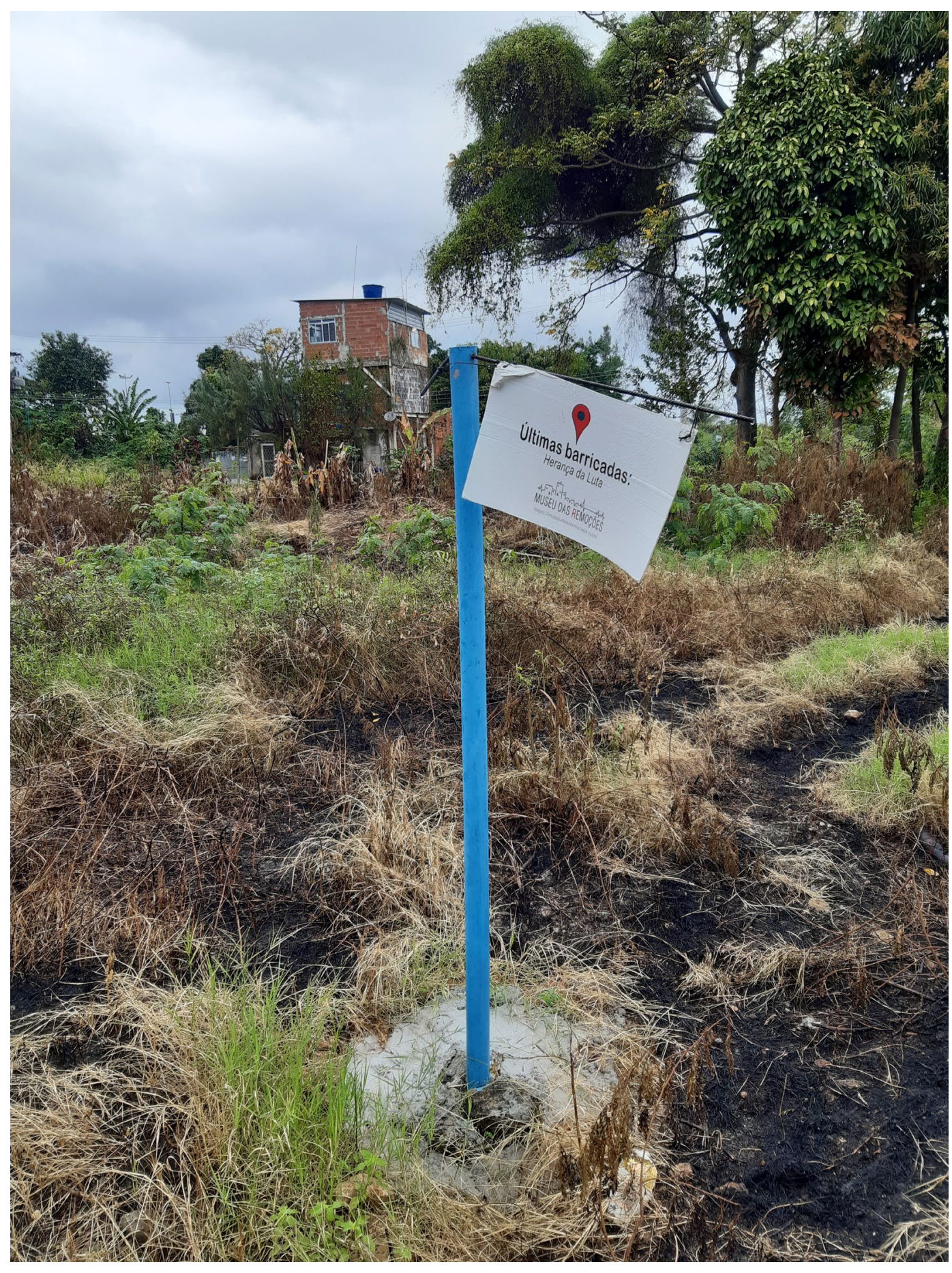

Figure 4. Last barricades, a landmark of the resistance against municipal guards. Museu das Remoções, Vila Autódromo, 2019. Courtesy of the Laboratory of Experimental Museology at the Federal University of the State of Rio de Janeiro, UNIRIO. 
make the devastated land into a sensitive space for the re-creation of our critical understandings of the city's geography.

It is worth mentioning that, due to the COVID-19 pandemic, the Museum of Removals temporarily stopped visitation in the area. Community members, with the assistance of collaborators, have created a series of videos presenting the specific points along the exhibition path, each narrated by one of the residents, which are uploaded on the IGTV of the museum's Instagram profile. ${ }^{4}$ Inspiring other activists and collaborators to join the cause against gentrification, the museum is open to all contributors, and every visitor is a possible supporter, in a Vila that is still struggling to survive the modernization of the city and the privatization of public spaces.

While in the Vila, it is not unusual for visitors and university students to be invited to have a cup of coffee with Dona Penha, or to participate in one of the community lunches and cultural activities over the weekend. In the spirit of making the Vila populated and alive, community members organize several cultural events, including the frequent exhibition of films followed by debates, picnics, and birthday parties that end up being nice gatherings for former inhabitants and volunteers. Also, there is the Football Cup of Vila Autódromo, organized every year by Luiz, involving teams made up from several communities, to which I was invited to participate with a team of players from my university. The exhibition, then, is a substrate of many possible "meshworks" that are constantly growing and changing, having the museum's cause as the main driving force.

While in the area looking at the ground, we see the images of the former Vila, which are juxtaposed to the fragments of buildings and streets that no longer exist, but are preserved in the land to activate our imagination of what once was. This exhibition effectively recreates the Vila Autódromo before the removals: a place that exists only in the memories of its inhabitants, a few of them still living there. Luiz, Penha, Sandra, Nathalia and many others: they are the living heritage being preserved and their lives are the content of this resilient museum.

Bruno Brulon Soares,

Universidade Federal do Estado do Rio de Janeiro-UNIRIO

\section{NOTES}

1. Social museology in Brazil can be defined as a movement involving small, experimental museums and their power to challenge the "classical" museum model and its traditional methods. It is inspired by the Latin movement of New Museology from the 1980s, and by the notion of the "integral museum" from the Round Table of Santiago de Chile (1972), both of which have oriented the development of "social museums" in the country.

2. For a detailed history of the removals and the motivations behind them, see the doctoral thesis by Diana Bogado, one of the museum's activists and co-creators: Diana Bogado, 2017. "O Museu das Remoções da Vila Autódromo: Potência de resistência criativa e afetiva como resposta sociocultural ao Rio de Janeiro dos megaeventos" (PhD diss., Universidad de Sevilla).

3. For a discussion of the idea of a critical geography, see: David Harvey, 2001, Spaces of Capital: Towards a Critical Geography. New York: Routledge.

4. Other than its website (https://museudasremocoes.com/), the museum uses social media as a resource to stay connected to its supporters and potential visitors during the long period of restrictions during the COVID-19 pandemic. Available at: Museu da Remoções Instagram: https://www.instagram.com/ museudasremocoes/?hl=pt (Accessed 15 May 2021).

5. Meshwork is the concept adopted by anthropologist Tim Ingold and refers to "the web of life itself;" see Tim Ingold, 2012, “Toward an Ecology of Materials," Annual Review of Anthropology 41: 427-442. 


\section{Different Histories}

\section{A Story of Three Exhibitions in Canberra}

National identities and histories are often in a state of flux. As public institutions of national history, Australia's Commonwealth museums and galleries in Canberra can be sites of debate and contention. They are always tied into the broader genre of history and the way in which those histories "are understood, represented, commemorated—and contested" (Message 2018: 136). Their exhibitions function as the public face of their collections and their history and are the medium through which they become known. Exhibitions are complex and collaborative undertakings and "set the priorities as to what is shown and when" (Mendelsohn, DeLorenzo and Inglis 2018: 11).

In 2020, the conventions of our world were shaken with the outbreak of a global pandemic. As well as the urgent practical necessities of dealing with COVID-19, the conservative Liberal/ National coalition Australian government, led by Prime Minister Scott Morrison, was beset by ongoing political protests with both global and national connections. Those included \#BlackLivesMatter and the perennially urgent issue of the treatment of Australia's First Peoples, violence against women driven by the \#MeToo movement and then playing out in a series of ugly rape allegations from within the government, and the revelation of potential war crimes committed by Australian Special Forces in Afghanistan, which are subject to an ongoing criminal investigation. In a year of crisis, three of the country's national cultural institutions launched temporary exhibitions intersecting with those very topical and contested subjects.

The exhibitions staged by the National Museum of Australia (NMA), the National Gallery (NGA), and the Australian War Memorial (AWM) provided an opportunity for each institution to represent some of the missing or marginalized voices in history, and for them to draw on their own collecting and exhibition histories to uncover and explore different kinds of omissions and silences. The exhibitions were well into the development stage by the time of the COVID-19 global outbreak, and physical openings to the public were delayed by shutdowns early in the pandemic. The NMA's Endeavour Voyage: The Untold Stories of Cook and the First Australians provided the opportunity to see Cook's exploration through the eyes of Australia's First Nations peoples. The NGA's Know My Name celebrates works of Australian women artists and confronts significant gaps of artworks created by female artists from within its own collection. And the AWM's Ink in the Lines examines the story of tattooing in the military as symbols of loss, trauma, memory, and regeneration. It is striking to reflect on them collectively, at a time when many of the world's master national narratives, Australia's included, are being profoundly and publicly challenged.

The launch of three temporary exhibitions in the same year, each questioning established productions of knowledge and ways of seeing, allows us to examine how Australia's national cultural institutions re-create national narratives through their exhibitions. We can ask how successful they are at attempting to reshape those narratives, or at least in issuing an invitation for us to reconsider well-established ways of telling and seeing.

\section{Dual Narratives: The View from the Shore}

The National Museum of Australia has had its own reckoning with nation-building narratives. When the museum's new building was opened in 2001, then Prime Minister John Howard 
denounced both the architectural design and what he described as the "privileging" of the narratives of First Australians, including the display of the "Bells Fall Gorge Massacre" exhibit in its First Australians Gallery. Howard's attack on the NMA was not merely criticism of "other" versions of history; "the object was to impose control on a public institution, to override the professional judgment of its staff and root out the exhibitions that challenged the critic's preferred version of history" (Macintyre and Clark 2003: 197-198). In the subsequent review of the NMA's opening exhibitions and program, the review panel argued for a balance between "grand narratives with diverse and more modest stories" (Carroll 2003: 7). Promoting a cohesive national identity was an important theme of the Review of the National Museum of Australia, chaired by John Carroll, and the idea of what Australian story the museum should tell continues to provoke debate, particularly when the museum attempts to explore diverse views and voices of Australian history. While the Review rejected the pluralist, historical approach adopted by the NMA towards its exhibitions, it was complimentary of the Aboriginal galleries, stating an "overwhelming consensus about the positive achievements of First Australians. This gallery serves as a model for much that should be aimed in some other parts of the NMA" (Carroll 2003: 20). As an odd foreshadowing, the Review's panel also recommended that: "James Cook should be a significant presence in the National Museum of Australia ... If modern Australia has a foundation myth it surely involves somewhere at its heart the figure of Captain James Cook" (Carroll 2003: 23). Seventeen years later, as part of the 250th celebrations, the NMA has tackled the foundation myth, although not perhaps as the Carroll Review panel might have imagined. Endeavour Voyage: The Untold Stories of Cook and the First Australians is the most recent temporary exhibition in which the NMA has explored Indigenous experience and perspectives of Indigenous history. Its 2017-18 exhibition Songlines: Tracking the Seven Sisters was celebrated as a milestone for curatorial practice and a broadening of Aboriginal narrative traditions. NMA exhibitions all follow an inclusive approach with Indigenous communities, as established by the organization over the past two decades, including exhibitions such as Kaninjaku: Stories from the Canning Stock Route and Encounters.

With Endeavour Voyage, the NMA gives us the view from the shore, as well as from the ship. We are presented with two sets of material culture and two different worldviews, forms of knowledge, and sightlines. It offers us a broadening or a re-reading of the traditional history, which has traditionally presented Cook and his crew's perspective of that journey. The Endeavour's voyage is traced from landfall in Tasmania to Possession Island in the Torres Straits. It is an ambitious exhibition, aiming to enhance our understanding of the beginning of Australia's colonized history and the impact on the original inhabitants. The show is imaginatively laid out, visually marking the difference in the dual narratives so the viewer can see and feel the difference between walking on the ship's wooden planks and walking on the land. A striking and dramatic installation representing three waterspouts rising out of the sea, as observed by the Endeavour crew on the same day they first saw the Australian coastline, forms the introduction to the gallery space. For them it was a curiosity-for those on the shore it was a bad omen, a warning. According to their traditions and oral history, "those waterspouts represented the spirit of the Ancestors ... they look beautiful, but they have a bad message. If we saw them out on country, we would pack up and go home" (NMA caption label).

In 2019 a group of artists from Yarrabah (Cape Grafton) created their response to the anniversary, depicting Cook and his crew as white devil spirits, sculpted from rainforest driftwood, shell, and bone. They found their materials on the shoreline that the Endeavour had sailed along. For those people, their evocative sculptures imagine Cook and the sailors as ghosts. Some of their works are on display in the exhibition. 


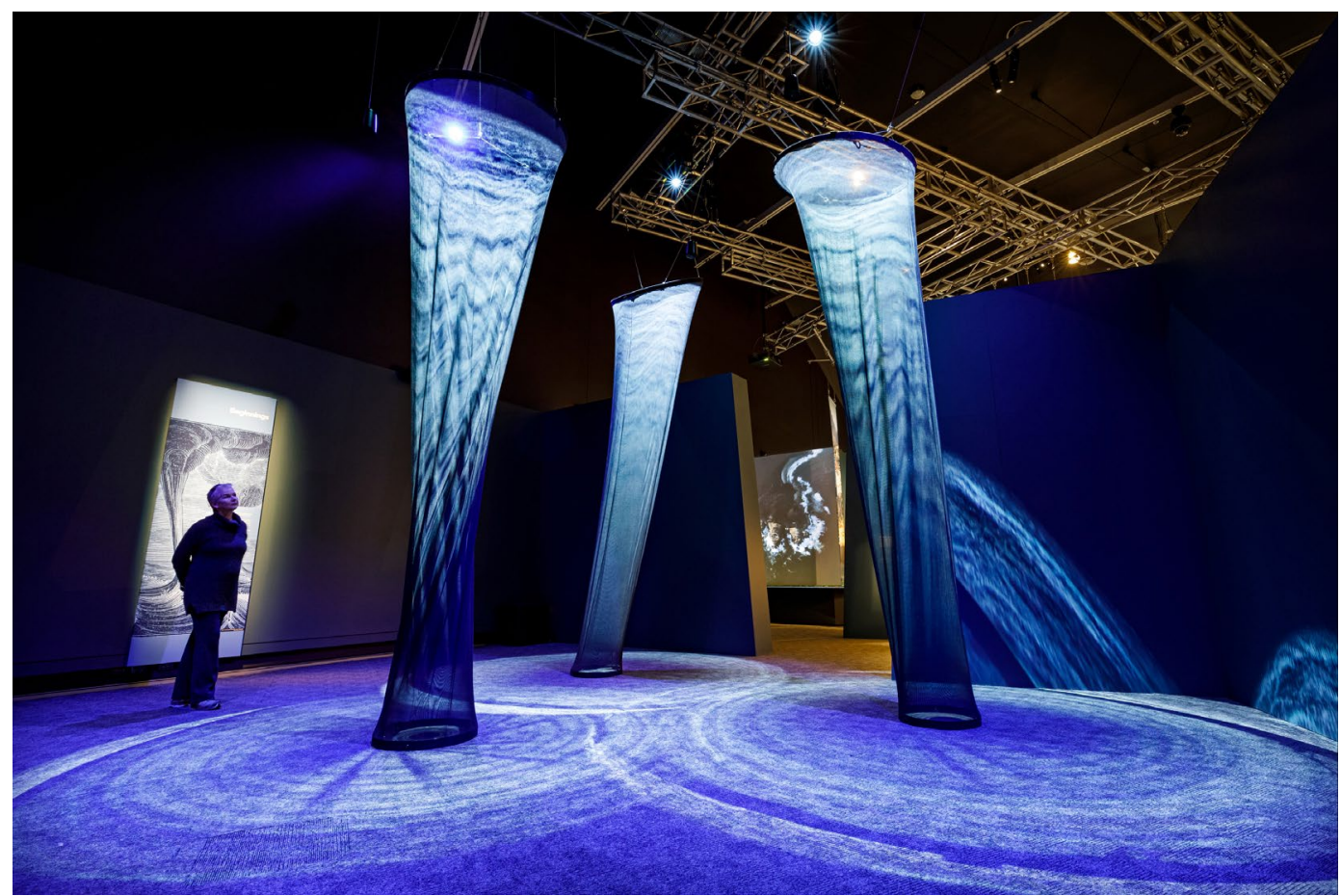

Figure 1. Waterspout installation of Endeavour Voyage: The Untold Stories of Cook and the First Australians. Courtesy of National Museum of Australia, Canberra.

There are many traditional objects shown, including the journal of the Endeavour voyage, loaned from the National Library of Australia, and a 1776 portrait of Cook by Nathaniel Dance. It is reputed to be a close likeness and depicts him as clever, authoritative and self-confident. But that image by a Western artist is challenged with other depictions, including Vincent Namatjira's Cook portrait that reimagines him as seeing new things that he might have missed in 1770 . The painting shows him in profile gazing across the water through a telescope, looking into the red soil and ghost gums of Australia. There are also breathtaking works by professional artists, including the exquisite 2018 painting by Cheryl Davison of Gulaga (Mt. Dromedary on the south coast), demonstrating that, where locals saw the contours of a woman's body in the landscape, Cook saw a camel. Bidjara photographer Michael Cook's photographic series Invasion recasts the events of 1770 as 1960s London being invaded by Australian Indigenous people and animals in a large spacecraft.

One of the central works, forming the heart of the exhibition, is a film re-imagining the lives of the First Australians during first contact. The Message was created by Alison Page, a descendent of the Walbanga and Wadi Wadi people, and director Nik Lacalczak. A dazzling, immersive visual experience that includes stunning coastal footage, it invites you to relook at the events of 1770 "and embrace a shared history of this country" (National Museum of Australia, n.d.). A contemporary re-enactment of Cook's voyage up the east coast of Australia, featuring descendants whose ancestors witnessed this event, reimagines the news of Endeavour's arrival being passed up the coast. The film powerfully brings to life objects that you see in the physical exhibition; spears, shells, and message sticks. 


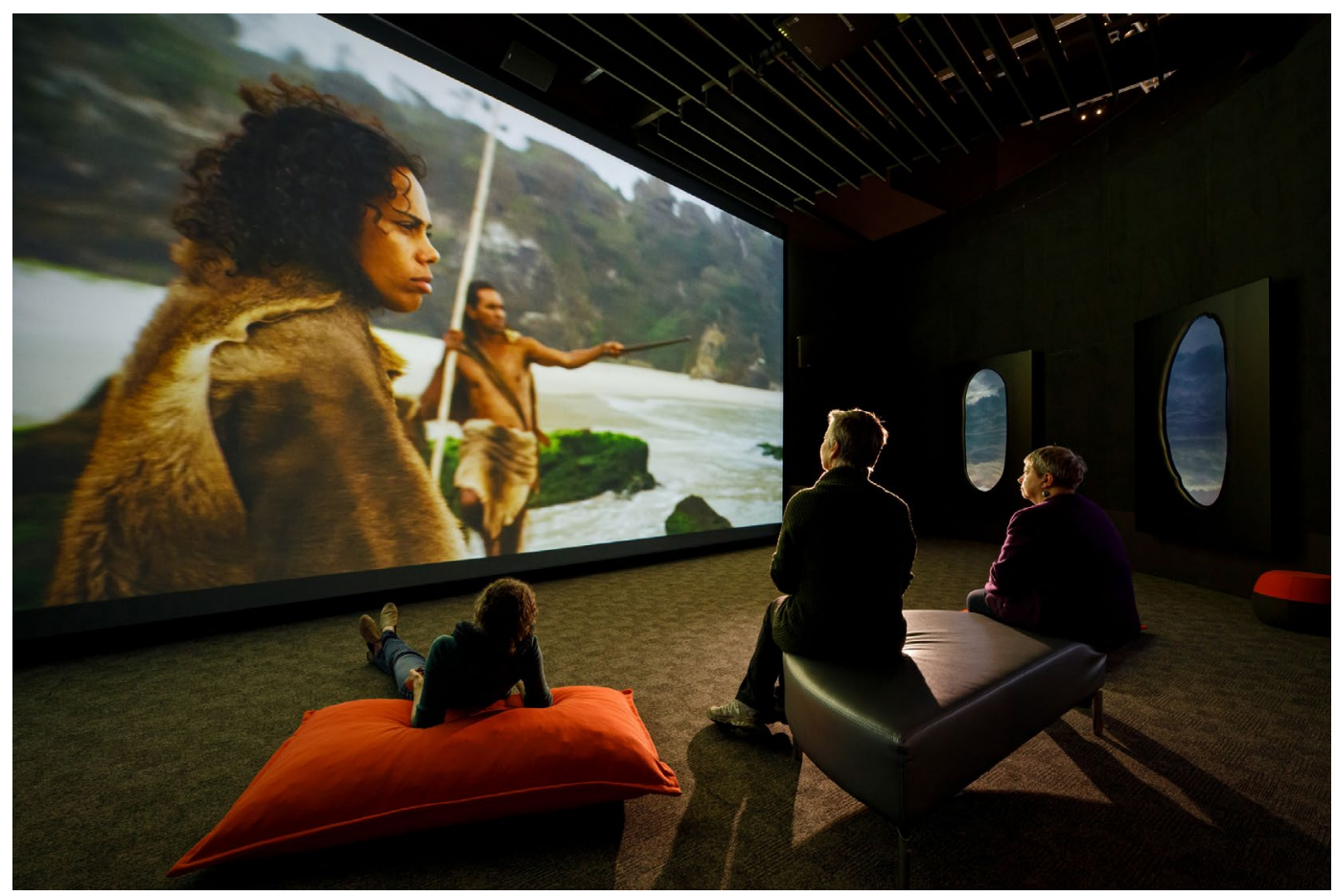

Figure 2. Scene from The Message by filmmaker Alison Page.

Courtesy National Museum of Australia, Canberra.

Endeavour Voyage is an entrée into the complex and rich cultural world into which Cook and his men ventured. It gives us a glimpse into previously neglected stories that are now placed in a central narrative in the history of the voyage, asking us to rethink what we know about those events and to expand our narrative to include long-absent Indigenous Australian voices.

\section{Know My Name: Repositioning Women in Australian Art History}

The NGA's Know My Name: Australian Women Artists 1900 to Now grew out of the institution's reckoning with its own history, biases and gaps in its collection and exhibition program. As Australia's national gallery, the NGA has recently recognized the paucity of women's art in its collection. During the media launch of the exhibition NGA Director Nick Mitzevich emphasized that this much anticipated reimagining of women artists in Australian art history is not a survey, but rather "a series of vignettes" (Fairley 2020). He also positioned Know My Name as part of a broader agenda that he wanted for the NGA, "which is to lead a progressive approach to art" (Brook 2020). For Mitzevich, "progressive" in that context meant a review and revision and new presentations about art and Australia: "There are real social, political and cultural issues at play in Australia. And our job is to make sure that we connect historical art with the present ... when you want to contribute to the cultural life of a country and community you have to put ideas out there that people will consider" (Brook 2020). In October 2019, Mitzevich announced that the NGA now aims for gender parity across the organization, including everything from collection acquisitions to its governance structure. In another interview with the Australian Arts 


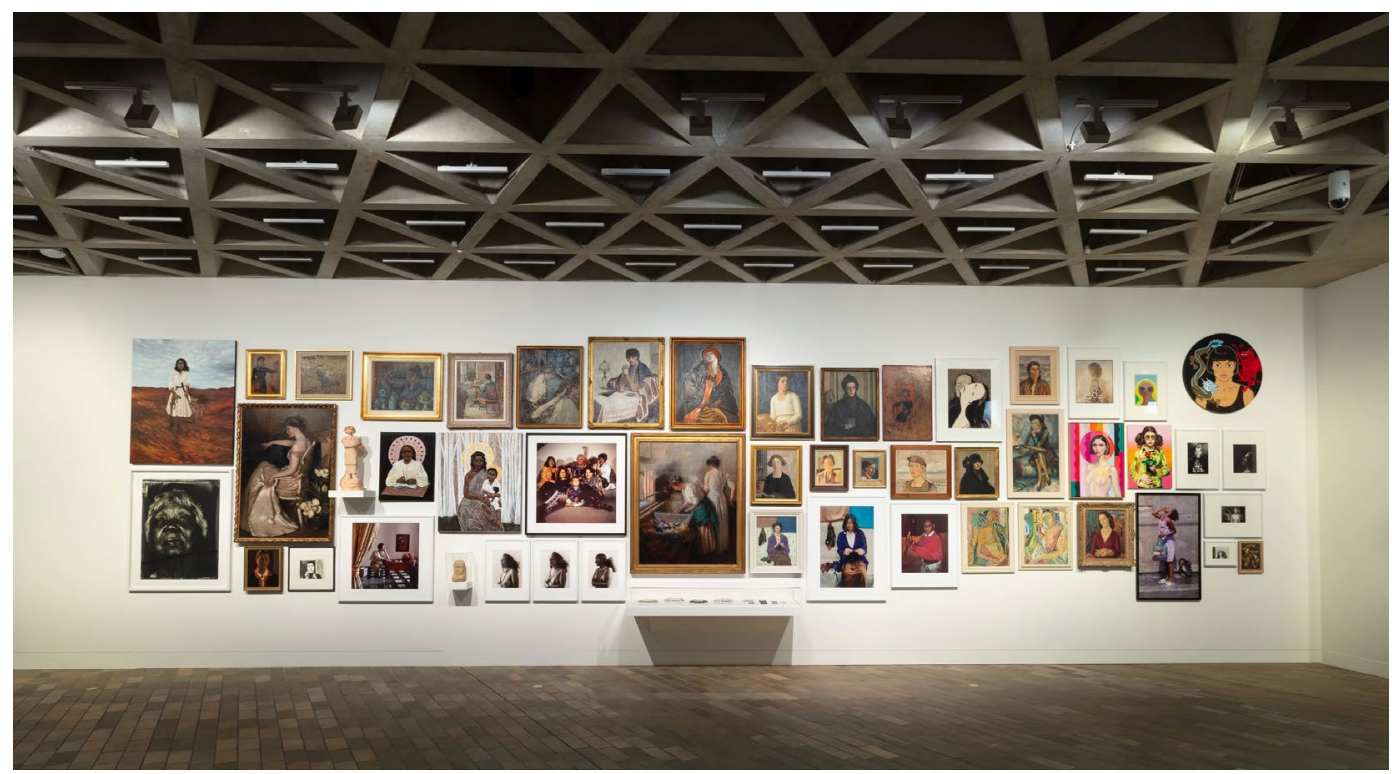

Figure 3. Installation view of Know My Name: Australian Women Artists 1900 to Now. Courtesy of National Gallery of Australia, Canberra

Review, Assistant Director Natasha Bullock said that the exhibition aimed to tell a new story of Australian art by "turning up the volume on the many previously unheard voices" (Australian Arts Review 2020).

Like Endeavour Voyage, Know My Name is a big and ambitious show, being one of the largest exhibitions of its kind in Australia, with over 350 works created by 170 women artists. Conceived by NGA curators Deborah Hart and Elspeth Pitt, it has been divided into two shows, with part one running until early May 2021 and part two opening in July. Some of the artworks displayed are drawn from the NGA's own collection but many have also been loaned from collections around the country. The NGA commissioned work for the exhibition, including the installation Kungkarangkalpa (Seven Sisters) by Ngaanyatjarra Pitjantjatjara Yankunytjatjara women, Tjanpi Desert Weavers. It is one of the first works that you see in the room dedicated to First Nation artists. It is preceeded by the opening wall of fifty portraits and self-portraits in a salon hang that crosses mediums and eras. It includes self-portraits painted by Nora Heysen (1932) and Stella Bowen (1934), Brenda Croft's beautiful black and white portrait of Dr. Aunty Matilda House (Matilda 2020), and Julie Dowling's painting honoring First Nations mothers whose children were stolen from them (Black Madonna: Omega 2004).

Despite the director's modest claim of "vignettes," it is a carefully curated exhibition exploring the story of art by women in Australia over the past century. It includes some well-known works by important female artists, including Destiny Deacon, eX de Medici, Marie Hagerty, Carol Jerrems, Margaret Preston, and Julie Rrap. The exhibition is crafted around seven themes: Connection with Country, Performing Gender, Collaboration and Care, Colour, Light and Abstraction, Micky's Room, Lineages and Remembering. Artist Gemma Smith was commissioned to select colors for the gallery walls, and she chose soft luminous shades reminiscent of her artistic practice. There is no linear timeline in the spaces. Rather, connections and associations are made across multiple points of reference, such as lineage, memory, and color, without strict thematic 


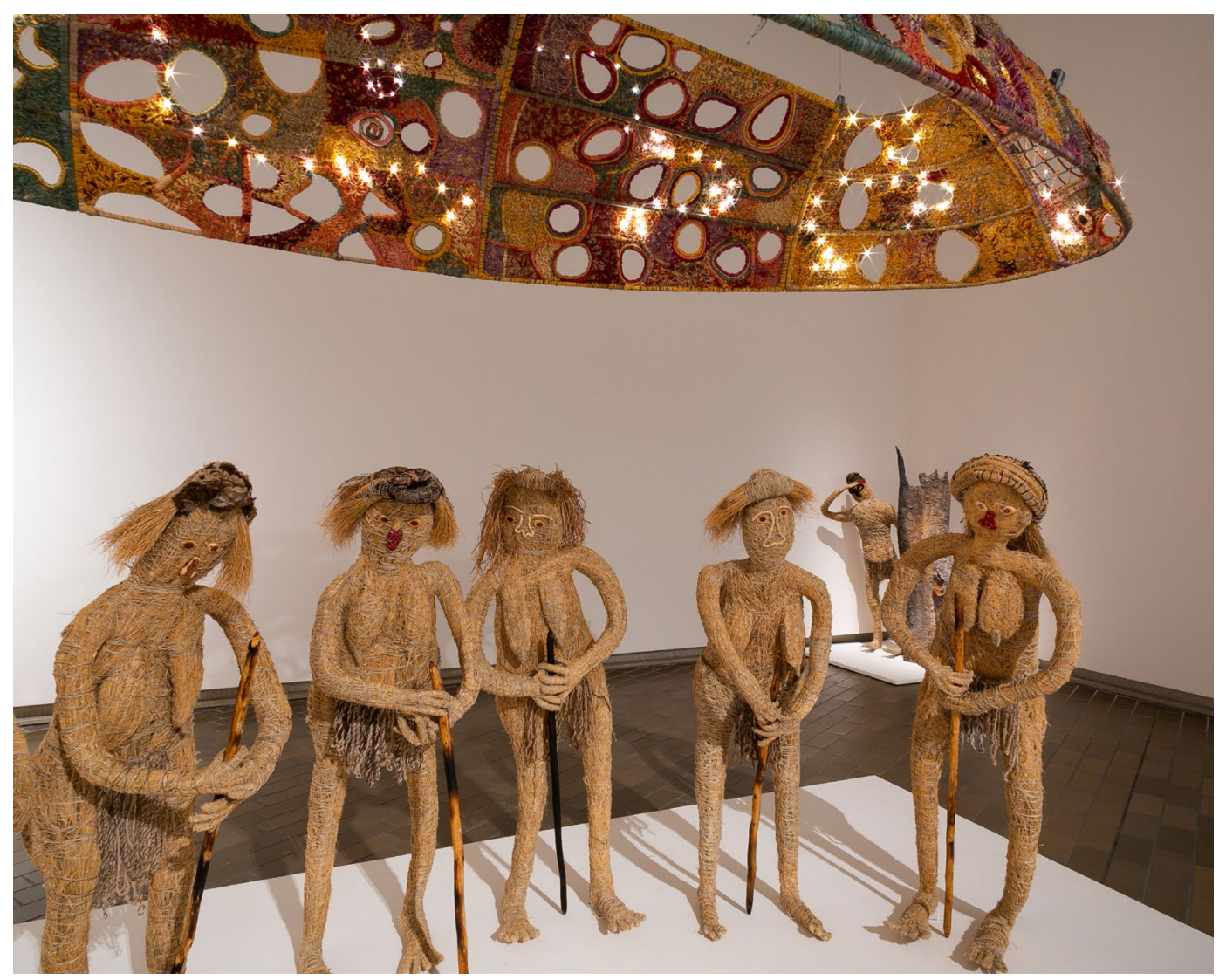

Figure 4. Tjampi Desert Weavers. Kungkarangkalpa (Seven Sisters) 2020. Warankurna, Ngaanyatjarra Lands, Western Australia. Courtesy of National Gallery of Australia, Canberra.

or chronological emphasis. Co-curator Pitt described "chronologies, really as a patriarchal construct," and the curatorial team chose "circular movements in time within specific groupings" (Hart 2020: 385). There are connections and affinities of environmental consciousness drawn between artists such as Rosalie Gascoigne and Emily Kame Kngwarreye. Portraits of women by women is another thread woven throughout the exhibition spaces, including Julie Dowling's powerful painting of her Aboriginal great-grandmother, Martha Lathan (Mary 2001).

Another room features a stunning photo series by Tracey Moffatt, Anne Ferran, and Julie Rrap. Rrap's series of dye destroyed photographic self-portraits, Persona and Shadow, reworks images by Edward Munch, reformulating the way in which women are presented in art. Mimicking the poses held by women in Munch's work, Rrap draws attention to the female archetypes he assigns - virgin, siren, sister-critiquing those depictions. Anne Ferran's Scenes on the Death of Nature (1986) hangs on the opposite wall as a series of five black and white photographs of groups of young and old women lushly draped in cotton sheets. It was produced early in Ferran's career and established her reputation as a leading photographic artist. She pays tribute to the forgotten histories of women by employing a classical scale and convention to the composition reminiscent of large sculptures. The women's faces are mostly in profile or turned away; some expressions seem anguished. They are images to be contemplated and considered before moving on. 
Know My Name is an exhilarating and timely statement in the wake of the \#MeToo movement that sets out to address the under-representation of women's art in the national collection and in Australian galleries. It remains to be seen whether the ongoing push for equal representation of female artists in the face of reluctance to include them and situate their practice in a traditional patriarchal canon will continue and be visible after the two exhibitions finish.

\section{Ink in the Lines: Stories Written on the Skin}

The Australian War Memorial is charged with helping Australians "remember, interpret and understand" the Australian war experience (Australian War memorial n.d. "Our organisation"). The National Museum's 2003 Review held the Memorial up as an exemplar of museum curatorial practice, with its presentation on a traditional grand narrative. However, scrutiny, and controversy, followed the announcement of a $\$ 500$ million-program of extensions in 2019. Its conservative position on the frontier conflict and refusal to include Indigenous warriors in its narrative of military history has been strongly criticized, including by its former Principal Historian Peter Stanley. In his view, war remains almost exclusively the Memorial's preserve and the collection is dominated by the uniformed services and combat. Stanley argues that, as a result, there needs to be "more of a premium on the need for a treatment of war that encompasses a range of attitudes, value and interpretations" (Stanley 2011). Despite the significance of war to Australia's history, apart from the Memorial it is not highly visible in other Australian museums, so there has tended to be one dominant interpretation: the classic reiteration of the Anzac legend, valorizing white men in combat.

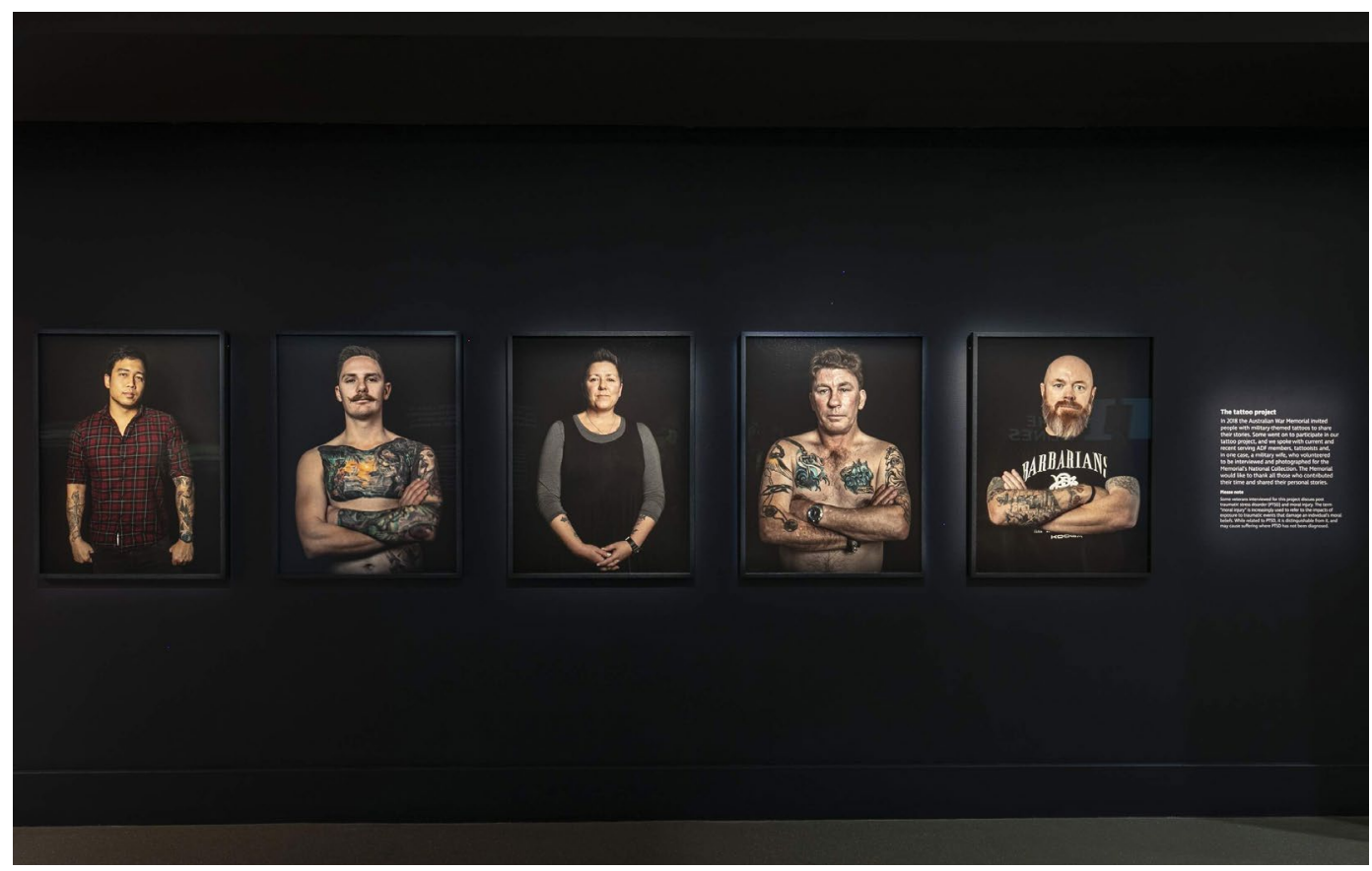

Figure 5. Portraits from Ink in the Lines AWM2020.4.86.7.

Courtesy of Australian War Memorial, Canberra. 
However, the Memorial has not been immune from some of the recent shifts in museology, and in recent years has focused on collecting around contemporary conflicts, as well as tentatively reassessing the role of Indigenous service in its travelling exhibition For Country, For Nation. While not uncontested, under former Director Brendan Nelson's leadership there was a shift of focus in more recent exhibitions towards considering the emotional and physical trauma of war.

Ink in the Lines, which showed in the AWM's temporary exhibition space, is the first exhibition centered on the long-established custom of tattooing on Australian military personnel. It explores the connection between the personal experiences of Australian veterans in contemporary conflicts and the inked designs they chose that helped them reflect their stories. Its focus is less about the experience of battle and more on personal and private stories. Ink is concerned with how veterans remember and move on when they return. As one interviewee says: "Specifically for the War Memorial as well, [it is] very important to show that [there is] another history within our military history" (Australian War Memorial n.d. "Ink in the Lines").

In 2019, AWM curator Stephanie Boyle worked with videographer Stephen Toaldo and photographer Bob McKendry to interview Australian veterans, exploring the personal stories behind their tattoos and how their permanence as "stories written on skin" commemorate the experiences of trauma, loss, and recovery. Presented in a darkened gallery against black walls, Ink comprises more than seventy portraits of twenty-one Australian servicemen and servicewomen and their tattoos, as well as oral histories in the form of video interviews. The exhibition is the visual end point of the Memorial's Tattoo Project, a combination of oral history and portraiture conducted throughout 2018 and 2019. The people featured come from a diverse range of experiences and backgrounds, joined together through their decision to be "inked."

In an interview, one respondent described veterans' identities as being inscribed on their skin. Recalling how the project developed, she explained:

We have a huge number of photographs and films of Australian military people and we noticed there were a lot of people with tattoos in these photographs and films. But I'm an oral historian and I read and conduct a lot of oral histories with people, and I noticed that they weren't talking about tattoos. So on one hand there's very strong visual evidence of people wearing tattoos in the military ... and yet that story is not obvious, it's not been told. (Australian War Memorial 2018)

Ink is divided into four thematic spaces: Loss, Grief and Commemoration, Therapeutic Mateship, and Identification and Belonging. The viewer is steered through a journey of personal stories, with candid emotional accounts recorded from the participants. The images are beautiful. The predominant use of photography, oral history, and video interview is unusual for a Memorial exhibition, which tends to privilege $3 \mathrm{D}$ objects. It is rare for photography to be one of the primary forms of communication and for multi-media to play such a significant role in communicating a story. There are no written captions; the related interview is the aural caption recounting the experience behind each face and each tattoo. The participants are simply identified by their first names, without rank, and their experience is revealed through their words.

As Kevin, one of the interviewees, says: "Most people get a tattoo for a game of footy. We get a tattoo to remember and commemorate: our service, our mates, our careers ... the blokes we serve with. Still serving." Or Deb's recounting: "A lot of civilian people get the anchor because they're stable and they're not going anywhere, whereas for me it represents my life, what helped shape me, and for what I've been through. Yes, it represents my naval career, but the flowers represent I was a female in a man's world. I'm not a pushover anymore." 


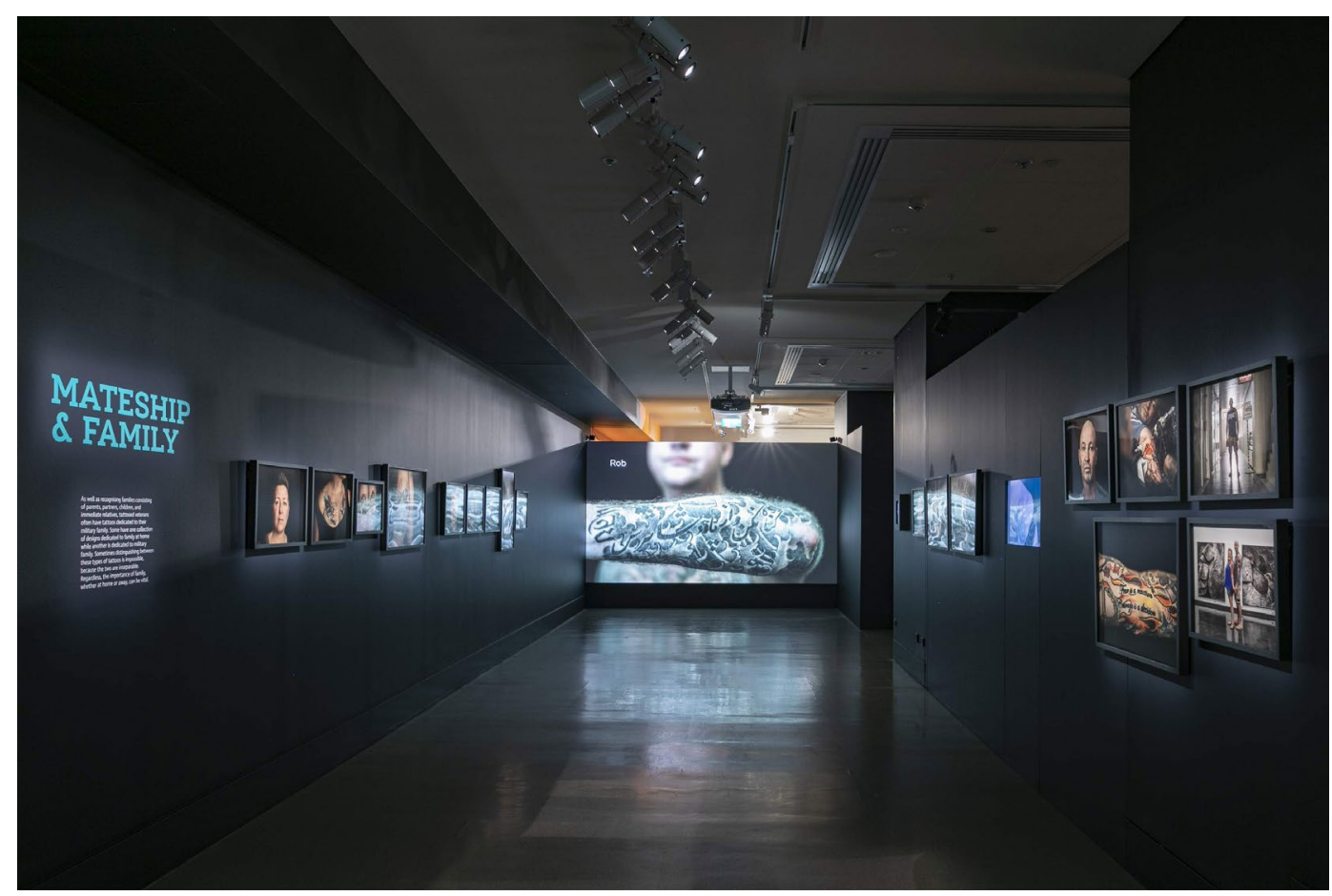

Figure 6. Gallery view of Ink in the Lines. Courtesy of Australian War Memorial, Canberra.

Ink in the Lines has some visual and thematic continuity from After the War, the AWM's 2018 exhibition that was concerned less with the details of battles and conflicts than with the post-conflict social, mental, and cultural impact of war on Australians. The prominence of individual voices and of photographic portraiture created a moving and personal experience, broadening the military history narrative to include tattooing in the story.

The exhibitions Endeavour Voyage, Know My Name, and Ink in the Lines all examine silences in Australia's public history and give them a voice in their gallery spaces. The staging of them has involved a closer collaboration of national institutions with different communities, including through art commissioning and collecting oral histories. They attempt to broaden the public record, and to use material culture to interpret and reimagine a range of new perspectives and meanings. While the NMA, NGA, and AWM each have their own complex relationships with Australian history, collectively we see an attempt to craft and stage exhibitions that are prepared to challenge established paradigms.

Jennifer Coombes, Australian National University 


\section{REFERENCES}

Australian Arts Review. 2020. "Know my name: Australian Women Artists 1900 to now." 11 November. https://artsreview.com.au/know-my-name-australian-women-artists-1900-to-now/

Australian War Memorial. n.d. "Ink in the Lines Videos." https://www.awm.gov.au/visit/exhibitions/ ink-in-the-lines/videos (Accessed 8 May 2021).

Australian War Memorial. n.d. “Our organisation." https://www.awm.gov.au/about/organisation (Accessed 8 May 2021).

Australian War Memorial. 2018. Telling Their Stories - Stephanie Boyle. Australian War Memorial YouTube Channel, 3 May. https://www.youtube.com/watch?v=AQsejVRkFUI.

Brook, Stephen. 2020. "Historical imbalance will finally be corrected." The Australian Review, 21 February. https://www.theaustralian.com.au/arts/review/women-put-in-the-frame/news-story/ 2b0ce757a1bf7f728369c4cddbb046be (Accessed 5 May 2021)

Carroll, John. 2003. Review of the National Museum of Australia: Its Exhibitions and Public Programs. A Report to the Council of the National Museum of Australia. Canberra: Department of Communications, Information, Technology and the Arts.

Fairley, Gina. 2020. "Exhibition Review: Know my name, National Gallery of Australia." Visual ArtsHub, 18 November. https://visual.artshub.com.au/news-article/reviews/visual-arts/gina-fairley/ exhibition-review-know-my-name-national-gallery-of-australia-261466 (Accessed 6 May 2021).

Hart, Deborah. 2021. "Know my name. Australian women artists 1900 to now." Pp. 385-390 in Know my name, eds. Natasha Bullock, Kelli Cole, Deborah Hart and Elspeth Pitt. Canberra: National Gallery of Australia.

Macintyre, Stuart, and Anna Clark, 2003. The History Wars. Melbourne: Melbourne University Press.

Mendelsohn, Joanne, Catherine De Lorenzo, Alison Inglis, and Catherine Speck. 2018. Australian art exhibitions: Opening our eyes. Port Melbourne, Victoria: Thames and Hudson.

Message, Kylie. 2018. "Making history in contested Times", Museum International, 80 (3-4): 136-145.

National Museum of Australia. n.d. "Endeavour Voyage: The Untold Stories of Cook and the First Australians." https://www.nma.gov.au/exhibitions/endeavour-voyage (Accessed 13 May 2021).

Stanley, Peter. 2011. "War and Australia’s Museums." In Understanding Museums: Australian Museums and Museology, ed. Des Griffin and Leon Paroissien, 1-6. Canberra: National Museum of Australia.

\section{National Treasures}

\section{Airing New Zealand's History on the Small Screen}

In May 2020, New Zealand's first nation-wide COVID-19 lockdown remained in place. While some restrictions started to ease as we moved into Level 3, the majority of us were still spending most of our time in our homes surrounded by our belongings-the things that had kept us company, and kept us entertained, during the aptly named "unprecedented times." The seventh of May, however, marked a point in at which we once again began to see the now very familiar household clutter around us in a new light. TVNZ had put the call out for New Zealanders to "scour their homes in the search for treasures, objects, and taonga that have special significance to New Zealand and our history over the last 100 years" (TVNZ 2020) for their new show, National Treasures. The program would see Kiwis sharing their taonga (treasures) with a panel of experts at Auckland Museum, with one hundred items eventually being chosen for display 
in the Museum of New Zealand Te Papa Tongarewa (Te Papa). This review examines National Treasures as an example of public history and heritage making in Aotearoa New Zealand in the post-COVID world beyond the physical museum, as well as analyzing what "treasures" are and the role that brick-and-mortar museums play in helping to create and maintain a sense of national identity through taonga.

Public history is a practice with a long past in New Zealand. While it can come in many forms, and be described in many ways, Bronwyn Dalley summarized it as: "historical work undertaken according to the research priorities, agendas, or funding capacities of another party rather than being self-directed by the historian" (Dalley 2001: 9). The role that public history plays within society has become ever more significant as New Zealanders have continued to turn to formats beyond traditional books to get their hit of history. As technologies have continued to improve and become more accessible in a world where most have access to the Internet from their own phones, it has been noted that the average layperson increasingly wants to see history in museums, as well as on the large and small screen. Dalley reported in 2001 that when it came to history, New Zealanders "want to hear it and they want to walk through it" rather than reading about it (Dalley 2001: 11). Twenty years later it is clear to see that little has changed on this front, though new forms of media have helped to facilitate this-i.e., through things like social media and video-on-demand streaming services. This is where National Treasures comes into the picture. The program represents several of the non-text-based forms of public history, that of history made for the screen, in this case television; and also history as put on display in a museum exhibition.

Broadcast over four episodes from 7 March to 4 April 2021, and available through online streaming via TVNZ's OnDemand service, National Treasures aired to a viewership perhaps more aware of its identity and distinctive nature as a nation than it has been in many decades. New Zealand's prompt and systematic response to the threat of the COVID-19 outbreak and global pandemic has been the recipient of much praise, even from the World Health Organization (WHO) itself (1 NEWS 2020). Our response, however, has had several ancillary results beyond simply keeping our case and death toll at some of the lowest in the world. By closing our borders on 19 March 2020, our once thriving tourism and heritage industry all but disappeared. As the situation, and lockdowns, progressed, New Zealand heritage professionals were forced to adapt their approach to, and within, our local, regional, and national museums and heritage institutions. National Treasures can be seen as demonstrative of the response of the GLAM (Galleries, Libraries, Archives, and Museums) sector in shifting to a greater inward focus on New Zealand, and to New Zealanders, as they sought new nets of potential visitors following the total loss of international tourist revenue.

At its very core, National Treasures is a show about New Zealanders for New Zealanders. Made with support from NZ On Air and Te Māngai Pāho, the program embodies the GLAM sector's response to combatting closed doors and changed practices post-COVID-it recognizes that it must appeal to New Zealanders to succeed, both as a television show and as an exhibit representing one hundred years of our nation's history. Elizabeth Wood has proffered the idea that "the exhibition content that reflects localized interests and multiple perspectives aids museums in promoting visitor-oriented meaning-making" (Wood 2009: 25). National Treasures collates New Zealand taonga that can represent New Zealanders in many different ways, and through this process (by producing the show) Kiwi viewers are able to connect to some form of inherent New Zealand identity and sense of belonging. This connection is where the meaning-making lies. What enables the taonga that National Treasures presents to hold such connective potential is the story they tell; and pivotal to understanding this power is how we define what "treasures," or taonga, are. 
On a basic level, "taonga" can be defined as property, a treasure, or something highly prized (McCarthy 2018: 217). When it comes to further expanding on this description, it has been noted that, "much ink has been spilt trying to describe this most complex and elusive of Māori concepts" (McCarthy 2011: 132). In his institutional history of the first twenty years of Te Papa, Conal McCarthy's approach to clearing some of this mist around the concept of taonga was to present the views of some of the (then) current Māori professionals working within the museum. These various definitions remain useful in a consideration of taonga more generally, and in this case, in relation to the treasures that National Treasures presents on television. Huhana Smith, a former curator, spoke of taonga as: "Anything tangible or intangible to do with the accumulated value with regards to people's relations to it, including objects, stories, whenua, [and] awa" (Huhana Smith, cited in McCarthy 2018: 132). Smith's somewhat all-encompassing definition of taonga enables us to see that the potential for something to be taonga or a treasure is ever present, with the perceived, inherent, or accumulated value a person ascribes to something being that which crystalizes its status as taonga.

The sentiment that underpins Huhana Smith's definition of taonga is reflected by both Stacey and Scotty Morrison (National Treasures' co-hosts) in their own discussions of what taonga is, and what the kind of treasures were that the show was seeking out to display. Stacey stated that, “Things aren't important... it's about taonga, or valuable treasure, however you perceive that to be" (Barry Hill 2021), thus highlighting the importance of value ascribed to artifacts (in the multiple forms they come) in turning them into treasures. Scotty's opinion on taonga that hold importance for all of Aotearoa New Zealand is similarly centered by the significance of the value given to them through the act of storytelling. "Things become national treasures when the backstory becomes important," he said, "when the backstory links us to our past and educates us about who we are" (Barry Hill 2021). The way in which National Treasures facilitates, and is structured around, storytelling in relation to taonga is where the show really succeeds in presenting accessible, interesting, representative, and emotional public history. One of the show's experts, Nina Finigan, remarked: "We all know this, but you realize history truly is made up of people, and their stories. It's very obvious and beautiful and sad all at once" (Victoria University of Wellington Te Herenga Waka 2021). These histories have staying power due to the way in which they have been told-i.e., by those New Zealanders who brought their taonga to Auckland Museum to be assessed by the program's experts in the first place, and who helped humanize these parts of our history, allowing viewers of the show to also make personal connections with them.

In his chapter titled "Fabricating Heritage" for the edited collection Cultural Heritage, David Lowenthal argued that, "Heritage like life history must be above all our very own. Only a heritage that is clearly ours is worth having" (Lowenthal 2007: 119). In Lowenthal's view, then, heritage and the histories that museums and cultural institutions tell must be representative of a particular group, community, or even nation to hold any real value. Following this perspective, National Treasures needed to ensure that the storytelling it did around the taonga it displayed to the nation was, therefore, in some ways representative of the nation (or the audience) it was screening to in order for the show to attain any cultural hold. National Treasures curated a wide range of stories to represent different parts of New Zealand society-something that will be discussed more extensively below-and essential to the object of making this history "ours" in a New Zealand context is the centrality of kaupapa Mãori (Māori issues, topics) in the show.

A Māori presence is felt throughout National Treasures. Te reo Māori (the Māori language) is seamlessly integrated into discussions between visitors and experts, within the group of experts themselves, and even into Stacey Morrison's opening remarks-which are presented in English and te reo Māori. The use of te reo Māori-and the choice to not translate certain phrases or con- 
versations-seems very purposeful. While Stacey's opening speech does end with an expression of cultures coming together- "Kia putikitiki te taurahere tangata. Kia mau, kia renarena| Our diverse cultures bound together through threads of history"-National Treasures makes it clear to viewers that underpinning most, if not all, of the stories told, and heritage described, is Māori history. In his 2015 article "New Zealand History is Māori History", Nēpia Mahuika proposed that "New Zealand historians, and some Māori historians too, must realize that all New Zealand history is relevant to Māori and that Māori are relevant in all New Zealand histories" (Mahuika 2015: 6). Mahuika stated that in order for ethical historical scholarship to occur in Aotearoa New Zealand, tikanga, and the recognition of the above statement, must be the foundations of any history produced (Mahuika 2015: 5). From this outlook, Māori are brought back into the national, nation-making, and national identity narratives. In a nationally broadcast show calling itself National Treasures, Mahuika's approach is therefore essential in the creation of public history for a New Zealand audience.

The presence of Māori history discussed amongst Māori and for a Māori audience can be seen in parts of National Treasures. For instance, it is often the case on the show that when taonga was brought in by Māori kaitiaki to Auckland Museum, the discussion with the museum expert was held in te reo Māori. Māori were thus able to speak to their own histories and taonga in the way of their choosing. In the first episode, for example, Stacey took on the expert role in the segment with the great-grandson of Wiremu Kerekere, Manaia, who had brought along the case used by his tipuna (ancestor) during his time in Māori Radio Broadcasting. Wiremu Kerekere was involved in iwi (tribal) broadcasting, and was also a trailblazing figure in national radio during the early period of the revitalization of te reo Māori broadcasting (National Treasures episode 1). Therefore, the fact that Stacey and Manaia are able to körero (discuss) Wiremu in te reo is intrinsically related to, and reflective of, the history the selected taonga represents.

In the second episode, Scotty, during one of his travels across the country to visit the taonga that "couldn't quite make it [to the museum] on the day" (National Treasures, episode 2), met with Hinerangi Puru, the daughter of Dame Whina Cooper. They spoke about the pouwhenua (staff) that was carried at the front of the 1975 Land March, and that is now held at Waitangi. Here, in such a historically significant place (Waitangi), and with such a prominent wähine Māori, the use of te reo is utterly natural and entirely pertinent to the narrative the taonga speaks to. Additionally, there are other examples of Māori-specific taonga throughout the show-such as a flag from the occupation of Bastion Point, and the watch of Sir Syd Jackson-but the broader point is that even in the stories of taonga that do not quite so obviously have a connection to Māori as these examples had, te reo is still utilized, and so are tikanga (cultural practices) around Kaitiakitanga (stewardship) and respect. National Treasures thus demonstrates how Mahuika's point about the responsibility of all to recognize all New Zealand history as Māori history can be put into practice.

Much has been said by museum professionals and practitioners about biculturalism within museums in Aotearoa New Zealand (McCarthy 2011, 2018; Tamarapa 1996). Whilst this review will not delve into a discussion of this discourse, we can see how the notion of biculturalism itself in this context also feeds into Mahuika's ideas around New Zealand history being Māori history, and the responsibility of all New Zealanders - but particularly Pākehā (European New Zealanders) - to recognize this. When it comes to National Treasures, the ways in which it embraces kaupapa Māori help to subvert the traditional ways national New Zealand histories have been told-especially prior to the period of the "Māori Renaissance" in the late twentieth century, and particularly in large-scale, encyclopedia-style written versions of New Zealand's history.

Discussions about biculturalism within the New Zealand context do also throw up questions around how the nation is defined. In fact, certain museologists see the next steps beyond the 
paradigm of biculturalism to be "bi-nationalism," and the recognition of a self-determined Māori nation existing alongside a Pākehā/settler nation (McCarthy 2018: 141). National Treasures provokes certain parallel questions in relation to definitions of a nation in several ways. Firstly through its own name-National Treasures-which leads onto a second consideration of who makes up that nation and whose treasures are being put on display on a nationally broadcast television channel (as well as online via OnDemand), and also, consequently, in the national museum, Te Papa. The production of National Treasures has been very timely-and perhaps responsive to-discourse about the concept of nations as prompted by the indiscriminate global pandemic experienced in 2020 (which is still ongoing as of this writing). "COVID helped us redefine ourselves," Stacey Morrison remarked; "We're constantly redefining who we are as a nation" (Barry Hill 2021). The pandemic has, especially in the way in which New Zealand specifically has experienced it, forced somewhat of a reckoning in terms of forcing us to rethink our own identity as Aotearoa New Zealand, and as New Zealanders, in a time when we have become very much physically isolated-more so than normal-from the rest of the world.

Another layer of this "nation" story also comes in the form of the historic challenges from marginalized groups to museums for their recognition from, and within, such institutions. Sharon Macdonald described how this "emphasis upon museums as projections of identity, together with the idea of museums as 'contested terrains', has become increasingly salient over the past decade" (Macdonald 1996: 10). The stories told in National Treasures, through the taonga shared with the experts (and the viewers), also reflects this expansion within museums of the kinds of people, groups, and identities their collections and exhibitions show. The program has experts talking with the kaitiaki (guardians) of taonga about the many aspects of our past. They speak to the nation's sporting history - through treasures such as a Black Magic jacket from New Zealand's winning America’s Cup in 1995, and the hat and jacket of New Zealand's first Māori Olympic skier, Simon Wi Rutene, through to New Zealand fashion history-with examples of costumes from the set of the 1980s show Gloss, and the "Power Jacket" made by the artist Rachel Rawlins, worn by MP Louisa Wall in Parliament during the $125^{\text {th }}$ anniversary of women's suffrage in New Zealand (National Treasures episode 3). Taonga display our music history too, with a framed ticket from Bob Marley and the Wailers' only New Zealand show (National Treasures episode 2), and a pin from a Front Lawn show (National Treasures episode 3), as well as our queer history, with taonga such as Hero magazines (National Treasures episode 1) and the first Civil Union certificate issued for a same-sex couple in 2005 (National Treasures episode 4).

Through telling these varied stories, National Treasures reflects the "diverse cultures" that Stacey stated are bound together through history, and also through the act of telling their stories. Histories of Pasifika communities in New Zealand are aired on the show through a number of taonga. In fact, one of the most emotional moments in the show comes in the first episode, when expert Oscar Knightley interviews a teacher about the treasure he had brought along-floor boards from his school that covered a hiding place where young Pacific teens were able to hide from immigration officials during the dark period of New Zealand's history that was the Dawn Raids (1974-1976) (National Treasures episode 1). Though Knightley himself had not experienced the raids, he knew many who had (Barry Hill 2021); and as a Kiwi of Samoan heritage, the emotional weight that such seemingly average objects-wooden planks-held, due to the history they represented, really impacted Knightley: it brought him to tears (National Treasures episode 1). Emotions run high throughout the program - from joy through to grief, and everything in between-and inform the way in which the public history told on the show is portrayed.

The purposeful targeting of viewer emotions is perhaps revealing of the ways National Treasures aims to unite New Zealanders through some kind of formation of a "national identity." "We need to talk about these histories, as hard as they may be," Matariki Williams, one of the 
show's experts, stated, "and having that told at a personal level is really important" (Victoria University of Wellington Te Herenga Waka 2021). The power of this combination of emotive and personal storytelling is most clearly demonstrated through the histories of disaster that some of the taonga tell-i.e., the taonga that already represent moments in which national identity and unity were tested or put on display. By mixing in these stories amongst those of treasures of a lighter nature-such as the props taken from the set of Lord of the Rings (National Treasures episode 2) - the show is able to bring together these somewhat disparate histories to form a more cohesive attempt at a definition of a New Zealand identity, an identity made up of these diverse stories, histories, and the groups that the taonga and narratives represent.

Steve Anderson suggested that television, and the capacity to re-examine and revisit such dark histories, has the therapeutic capacity to express, and also perhaps exorcise, a nation's collective trauma (Anderson 2001: 32). National Treasures facilitates this "therapy" through the telling of stories relating to the 2011 Christchurch Earthquakes-with the clothes worn by, and body tag given to, a woman who survived the collapse of the PGC Building (National Treasures episode 2). The concept of taonga is also presented by Scotty in Christchurch through his discussions with women who lost loved ones during the 2019 Christchurch mosque shootings, and who had brought along taonga owned by their lost whānau (family) — such as a medal and a footballand that also encapsulated the community response to this tragedy-i.e., the messages written by children and left by the mosques (National Treasures episode 1). Intangible taonga are also presented, such as the elderly man who turned his journal notes about the Tanigwai Railway Disaster of 1953, which he witnessed as a child, into a waiata (song) that captures the raw emotions of shock and grief about that event that he still feels to this day (National Treasures episode 1). The handcrafted diorama of a COVID-19 1:00 p.m. Press Conference meeting made out of recycled materials-with a recycled PM Jacinda Ardern and Director General of Health Ashley Bloomfield to boot-brings us back to our most recent national crisis and trauma ( $\mathrm{Na}$ tional Treasures episode 4). This taonga in particular shows the capacity for treasures to facilitate a form of therapy by working through, and also representing, those hard parts of our past in a New Zealand that has been intrinsically changed by this event. As Oscar Knightley commented, National Treasures is not just a "puff piece approach to history;" it works through some difficult but crucial parts of our past through its presentation of New Zealand history on screen, for the benefit of (and with respect for) all New Zealanders.

National Treasures airs New Zealand's past in a way that enables New Zealanders to come together and bond through the ways in which our diverse histories differ, but also intersect, and speak to a number of shared experiences that we have had as a nation. Though the show culminated in an exhibition at Te Papa, the form of storytelling around taonga that seemed most effective, and accessible, was that in its televised form. The traditional museum exhibit, whilst free, was only open at the national museum in Wellington for just over a month (8 March-18 April 2021), and lacked some of that real human connection that so brought the taonga to life in the television show. Even Jock Phillips-who was one of the experts on the show-noted in his book Making Histories: A New Zealand Story the ways in which digital mediums and those beyond white-walled exhibitions can be more effective in engaging a broader audience by bringing history to life in an immediate way (Phillips 2019: 306).

Though the television program and the resulting Te Papa exhibition represent many histories of a wide range of New Zealanders through the taonga and the stories they tell (and that are told about them), there do remain certain gaps in the national picture presented. "While television presents images of the national to the citizens of a territory," Shuchi Kothari, Sarina Pearson, and Nabeel Zuberi (2004) noted, "it 'hides' or marginalizes images and stories that are not considered central to national identity." Those most notably "hidden" in National Treasures are our disabled 
communities (Lodge 2021), and also our more recent refugee and migrant communities. The reasons as to why they were excluded is perhaps telling of how these groups are viewed in the nation-making narratives we tell ourselves, with their absence also underlining the criticisms members of these communities laid against the government for lack of specific attention and information provided to them during the COVID-19 lockdowns. A nation is made up of a great many moving parts, and this in part explains why a four-episode run of a show purporting to display the nation's treasures fails to address all these groups. In the future, however, it is important to recognize those that remain excluded from public histories of a nation, even if that story itself has already expanded and diversified greatly from the monocultural Pākehā history it once was.

National Treasures reflects New Zealand's inward turn in examining the nature of our nation, as prompted by the situation forced upon us following the pandemic. With international tourists, particularly international museum visitors, out of the picture for now, New Zealanders have the benefit of being more able to tell, and focus on, our own histories for ourselves. Through this process - and through programs such as National Treasures - the role of taonga in representing and creating a nation/New Zealand national identity has become ever clearer.

Ailish Wallace-Buckland, Victoria University of Wellington

\section{REFERENCES}

1 NEWS/AP. 2020. "World Health Organization praises New Zealand's response to Covid-19 again." TVNZ, 7 September. https://www.tvnz.co.nz/one-news/new-zealand/world-health-organization -praises-new-zealands-response-covid-19-again.

Anderson, Steve. 2001. "History TV and Popular Memory." In Television Histories: Shaping Collective Memory in the Media Age, ed. Gary R. Edgerton and Peter C. Rollins, 19-36. Lexington: The University Press of Kentucky.

Barry Hill, Rebecca. 2021. "Broadcasters Stacey and Scotty Morrison on their new TV show National Treasures.” NZ Herald, 18 March. https://www.nzherald.co.nz/entertainment/ broadcasters-stacey-and-scotty-morrison-on-their-new-tv-show-national-treasures/ AEKBHLKNMELV26UQVGRNOTEXN4/.

Dalley, Bronwyn. 2001. "Introduction." In Going Public: The Changing Face of New Zealand History, ed. Bronwyn Dalley and Jock Phillips, 7-13. Auckland: Auckland University Press.

Kothari, Schuci, Sarina Pearson, and, Nabeel Zuberi. 2004. “Television and Multiculturalism in Aotearoa New Zealand." In Television in New Zealand: Programming the Nation, ed. Roger Horrocks and Nick Perry, 135-151. Melbourne: Oxford University Press.

Lodge, Alex. 2021. "Review: National Treasures is a moving celebration of the objects that made NZ." The Spinoff, 4 April. https://thespinoff.co.nz/tv/04-04-2021/review-national-treasures-is-a-moving -celebration-of-the-objects-that-made-nz/.

Lowenthal, David. 2007. “Fabricating Heritage.” In Cultural Heritage, ed. Laurajane Smith, 109-124. Abingdon: Routledge.

Macdonald, Sharon. 1996. “Introduction.” In Theorizing Museums, ed. Sharon Macdonald and Gordon Fyfe, 109-124. Oxford: Blackwell Publishers.

Mahuika, Nēpia. 2015. "New Zealand History is Māori History: Tikanga as the Ethical Foundation of Historical Scholarship in Aotearoa New Zealand." New Zealand Journal of History 49 (1): 5-30.

McCarthy, Conal. 2011. Museums and Māori: Heritage Professionals, Indigenous Collections, Current Practice. Wellington: Te Papa Press.

McCarthy, Conal. 2018. Te Papa: Reinventing New Zealand's National Museum. Wellington: Te Papa Press. 
National Treasures, season 1, episode 1-4, aired 7 March-4 April 2021 on TVNZ. https://www.tvnz.co.nz/ shows/national-treasures (accessed 15 May 2021).

Phillips, Jock. 2019. Making History: A New Zealand Story. Auckland: Auckland University Press.

Tamarapa, Awhina. 1996. "Museum Kaitiaki: Māori Perspectives on the Presentation and Management of Māori Treasures and Relationships with Museums." In Curatorship: Indigenous Perspectives in Post-Colonial Societies: Proceedings, ed. Camilla Turner, 160-177. Ottawa: Canadian Museum of Civilization with the Commonwealth Association of Museums and the University of Victoria.

TVNZ. 2020. "Scotty and Stacey Morrison Kick Off Search To Find NZ's National Treasures" (Press

Release). Scoop, 7 May. https://www.scoop.co.nz/stories/CU2005/S00042/scotty-and-stacey -morrison-kick-off-search-to-find-nzs-national-treasures.htm.

Victoria University of Wellington Te Herenga Waka. 2021. "Museum studies alumnae find themselves National Treasures.” News, 25 May. https://www.wgtn.ac.nz/news/2021/05/museum -studies-alumnae-find-themselves-national-treasures.

Wood, Elizabeth. 2009. "Rules for the (R)evolution of Museums." In Inspiring Action: Museums and Social Change - A Collection of Essays, ed. MuseumsEtc, 24-41. Edinburgh: MuseumsEtc.

\title{
E Hina e! E Hine e! Mana Waahine Maaori/Maoli of Past, Present and Future
}

\author{
Waikato Museum / Te Whare Taonga o Waikato, Hamilton, New Zealand, \\ 14 September 2019-10 October 2021
}

From the darkness, a quickening echoes where potential resides. Here is the place of non-linear time where past, present and future meet. A womb of creation, where gestation of life is given substance.

Guided by our ancestors, we are transformed into future potential. $P \bar{o} / \mathrm{Te}$ Po holds the divine feminine and the beginnings of all life from the first single-celled organism, bringing us into the world in which we live today. ${ }^{1}$

Descending toward the exhibition mirrors lowering into Rarohenga, the realm of Hine-nuii-te-po,$^{2}$ the Maaori guardian of the dead. I look to the left and there is our waka taua (war canoe), Te Winika, her tauihu (prow) facing our ancestral awa (river) Waikato. Te Atairangi Kaahu, the late Maaori Queen, gifted her to Waikato Museum Te Whare Taonga o Waikato. To the right, the gown of waahine toa (warrior woman) Tuaiwa "Eva" Rickard, our renowned activist. Straight ahead, the waharoa (gateway) with cascading and life-giving wai (water) projected over the opening to te $p \bar{o}$ (the darkness, night). I am surrounded by the essence and impact of waahine toa.

One year in the making, this collaboration between Te Whare Taonga o Waikato and the University of Waikato Te Whare Waananga o Waikato smashes through prevalent mistruths on multiple levels. Using the exhibition for research dissemination, E Hina e! E Hine e! Mana Waahine Maaori/Maoli of Past, Present and Future brings into the public realm the indagations of Dr. Nālani Wilson-Hokowhitu (Kanaka Maoli), Dr. Aroha Yates-Smith (Te Arawa, Tainui, Horouta, Takitimu, Mataatua), and Curator Poutiaki Whakataki Maree Mills (Ngāti Tūwharetoa). The multimedia approach and density of content overload the mind and senses, leaving a lasting impact and encouraging deeper foraging and return visits. 


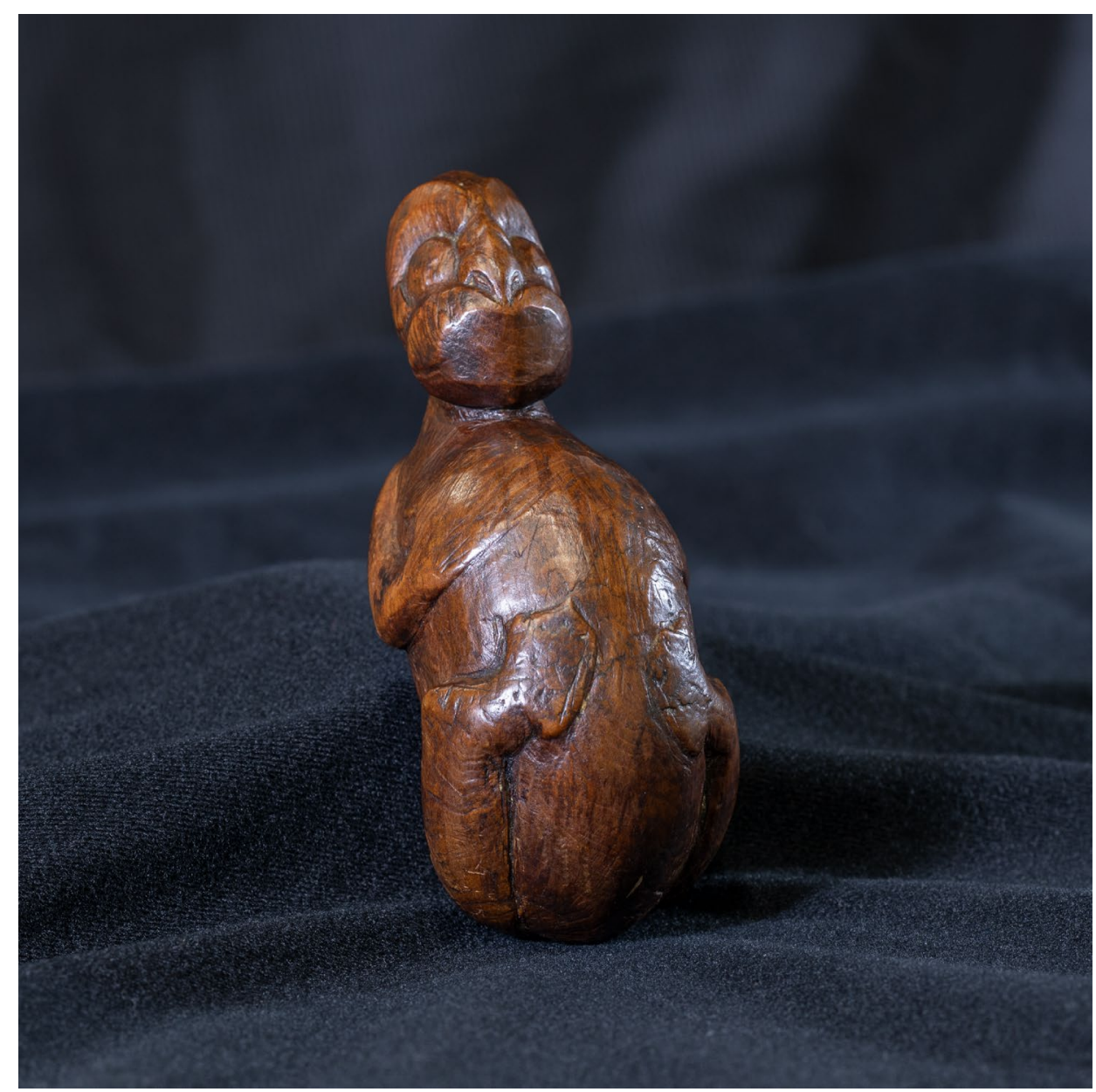

Figure 1. Taumata Atua. Unknown maker. Wood. Circa 1500-1800. Photograph by Jon Primmer.

The keystone of the exhibition is the celebration of the female essence, where the female voice takes center stage, supported by artworks, taaonga (treasures), fashion, and video. Presented from staunchly Maaori and Kanaka Maoli ${ }^{3}$ perspectives, the exhibition is deeply imbedded with recurring Pasifika symbols and motifs that have literally been built into the triangle doorways, ${ }^{4}$ koru layout, ${ }^{5}$ and multiple entries that support Maaori and Kanaka Maoli non-linear conceptualizations of time. The physicality of the space portrays the journey of all life from its beginnings in the womb of te kore (the void) through to today, reiterating the mana (power) that women hold as the bearers of life and death.

Housed in the pito/piko (umbilical cord, navel) and na'au (gut) of the exhibition is Taumata Atua (Resting Place of a God), a wood figure, circa 1500-1800 (see Figure 1). Unearthed on a Waikato farm, she has been connected to renowned female warrior leader Koura, as well as to the unborn child and to fertility due to her fetal form. It is around this Taumata Atua that the exhibition is formed. The na'au is the seat of knowledge, where our instincts begin (Noyes 2018: 376).

This "gut feeling" is valued in both Maaori and Hawaiian cultures, as is the pito/piko from which we are first grown and sustained through this connection with our mothers in the womb. It is also within the womb that we are, in the beginning, in a state of gender flux: "In the be- 
ginning, in Te Ao Maaori, male and female were a single being, undivided ... The tikanga of gender balance in Maaori are multiple and many" (Salmond 2018). By amplifying the voice of Indigenous Pasifika women, E Hina e! E Hine e! attempts to reclaim the centrality of waahine/ women in our Indigenous stories and knowledge, presenting from floor to ceiling with immense gusto our overwhelmingly feminine force in various iterations, as if to counter almost two centuries of marginalization. E Hina e! E Hine e! sets out to both correct our historical narrative and reconnect us to the feminine atua/akua (divine ancestors) embodiments and moolelo (stories). To repair the fragmentation of our culture and its teachings, we need to first restore balance to our Indigenous knowledge and reconnect to a complete version of our whakapapa/mookū'auhau (genealogy).

It is no secret that since colonization-and historically-men have dominated positions of power, and society has perpetuated patriarchal hegemony both actively and passively. Only recently have we fully begun exposing myths of gender roles in pre-colonial Aotearoa and the lasting impact they have had on Maaori women. Furthermore, the androcentric and Eurocentric early writings of Elsdon Best through to Berys N. Heuer perpetuated a negative view of Maaori women (Ralston 1993), creating an illusory truth effect as the repeated citing of these biases made them appear more credible. The male voice dominated and the female was omitted in what Yates-Smith calls "displacement of the feminine" (G. R. Yates-Smith 2018).

As Maaori life was sequestered further, our people absorbed a new, more patricentric belief system, the lessons of the puuraakau, and pakiwaitara (stories) of our waahine akua/atua became less known. Saved by the meticulous efforts of our tuupuna/kūpuna (ancestors) to maintain them, and of contemporary academics, who have dedicated themselves to recovering this knowledge, E Hina e! E Hine e! provides an elevated platform from which to begin the repatriation of these cloistered koorero (stories) into common knowledge. It is an important step in the right direction toward self-representation and re-establishing balance, as well as being a glorious irony that this platform is in a museum, considering museums' andro/eurocentric genesis: ${ }^{6}$ "Most of our deities and elements shift between that feminine and that masculine, that Ku and that Hinā. Within even the element itself. It depends on what your purpose and intention is. So being able to flow back and forth is very, very, very important" (Kanoelani Davis, quoted in "Laka," Wilson-Hokowhitu 2020a). Balance in all things is essential to Maaori and Kanaka Maoli worldviews, and this balance of gender in our atua/akua, environment and selves is shared with our Pasifika cousins. E Hina e! E Hine e! focuses on the power of our female deities, as te whare taangata (the house of humankind) protectors and as repositories for knowledge. The post-colonial phenomenon of elevating the role of a singular supreme male entity known as "Io" to prominence, and the reduction or outright removal of female influence in our stories have destroyed this balance, neutralizing female power and inflating male power (Mikaere 2019: 10).

An example is Hine-nui-i-te-pō, who has been misrepresented over time as the antithesis of life in order to make her power appear negative and frightening. However, her true story about her evolution from Hine-tiitama (goddess of dawn), through trauma, to choosing to become our guide at our most vulnerable, is particularly poignant and empowering. Hine-tiitama and Hine-moana embody the reality of this transition. Heartbroken, Hine-tiitama is comforted by Hine-moana, who enwraps her body as she heals. Dancer Bianca Hyslop and photographer Terri Ripeka Crawford capture the absolute deterioration of the world for Hine-tiitama, showing her softer more tender side and reminding us that it is from this place that she became our guide after death (see Figure 2), from a place of manaaki (care and protection), not revenge or anger. It is here, too, that she is complemented by Taane, who she compelled to stay and care for us, her children, in the living world. It is also important to note that this piece is placed beside the pito/ piko of the exhibition, echoing that this transformation is something of a rebirth. 


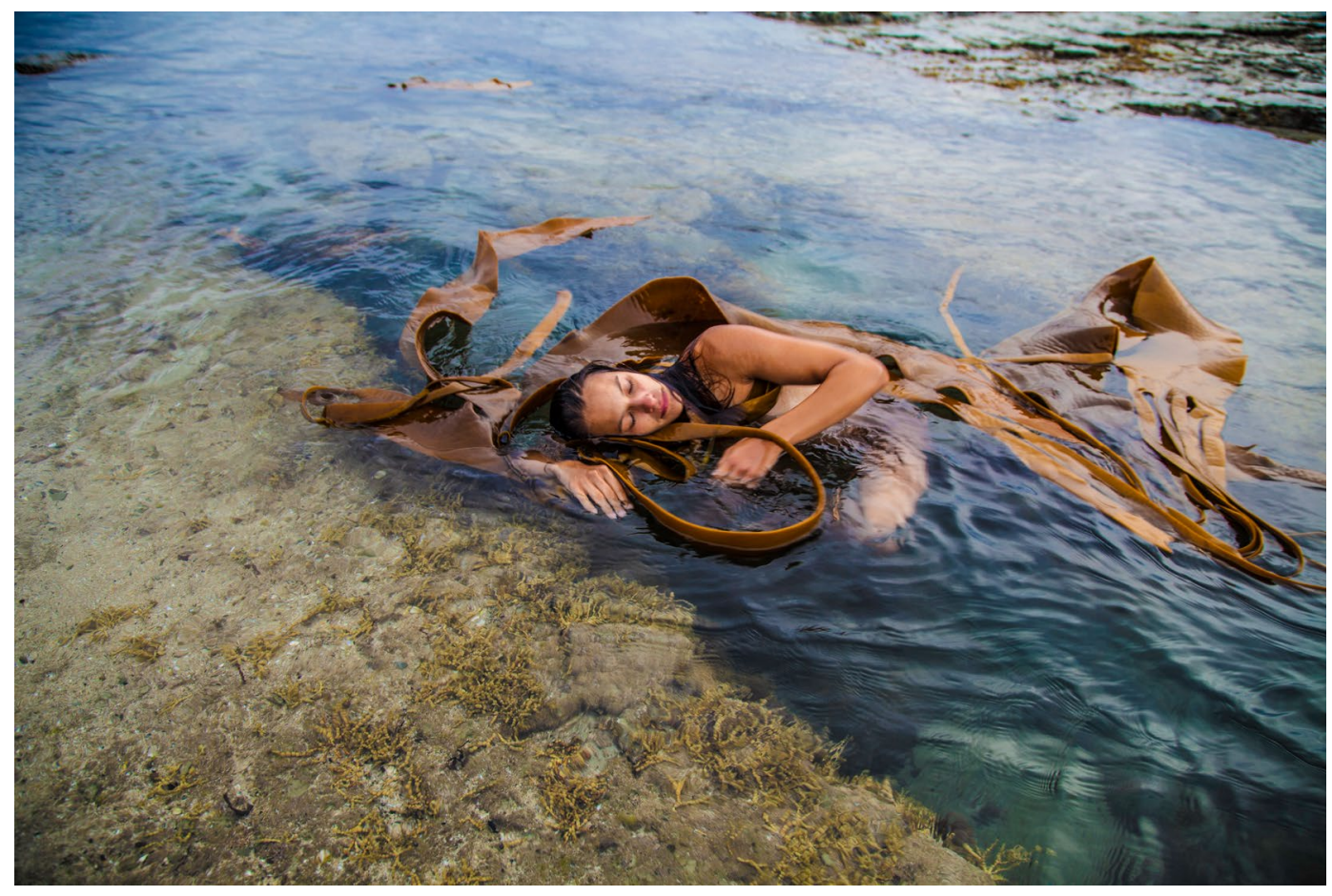

Figure 2. "Hine-tiitama and Hine-moana" by Terri Ripeka Crawford (Ngaati Porou, Ngaati Kahungunu, Ngaai Tuuhoe), Director/Photographer/Choreographer, and Bianca Hyslop (Te Arawa), Dancer.

If a waahine atua could not be made into a fearful deity, she was not recorded at all. The trope of the male warrior Maaori atua is so prevalent, that even to mention that they had complementary female counterparts of equal status elicits exclamations of surprise. As our Indigenous worldviews formed around the observation of the natural world, and the natural world is constantly presenting the continuation and evolution of life through complementary forces, be that cisgender, gender fluid, or by two opposing elements, it is rational to suppose we mirrored that within our cosmology as well.

E Hina e! E Hine e! seeks to restore gender complementarity and balance with the belief that this will create pathways to a sustainable future and may even be the key to our survival on this planet. Yates-Smith believes the benefits of knowing our waahine atua are that our women are empowered (A. Yates-Smith 2019a: 52), and empowered women are an asset to their communities and society. It could also encourage the adoption of a holistic Maaori worldview and a reconnection with spiritual knowledge. This could help taangata whenua (Indigenous peoples) ${ }^{7}$ cope with the pressures of materialistic standards of modern living and realign our focus with metaphysical and physical well-being (A. Yates-Smith 2019a: 56). We could also learn to value the view that we are holistically connected to our natural world through whakapapa and our responsibilities as part of this genealogy: "The consequences may have impact not only on the cultural, social and political scene but also on the environment, with people adopting a more caring and informed attitude toward Nature, thus affirming the importance of Papa and her offspring" (A. Yates-Smith 2019a: 56-57). Understanding how these stories support caring for our environment begins with understanding the importance of whanaungatanga (connectedness 
and kinship) through our whakapapa. These connections are nurtured through principles of manaakitanga (hospitality and caring), and kaitiakitanga (guardianship). It "sets forth a series of rights and responsibilities, commitments and obligations, and supports a collective purpose" (Wilson-Hokowhitu 2012).

Maaori and Kanaka Maoli trace whakapapa through to our primordial parents at the beginning of time, including all elements of the natural world not only as ancestors, but also as our elders. Connecting ourselves by using familial ties in this way acknowledges a whaanau/'ohana (family) relationship with all life around us. Therefore, as we are connected to the familial group, we have responsibilities as part of that collective. E Hina e! E Hine e! presents six video narratives that address these connections in various ways.

The first is "Porele and Kumulipo" (Wilson-Hokowhitu 2020d), which plays just after te pō as we enter into the realm of the elemental waahine atua/akua in our water, our volcanic activity, and our lands. Here, Maile Naehu (Kanaka Maoli) explains the Kumulipo, a Hawaiian creation chant that comprises 2165 lines. This chant was composed for an ali $i$ (ruling chief) to show his genealogy back to the beginning of time through to the birth of life with Kumulipo (male element) and Póele (female element). Maile explains that this humbles us as humans, because in the grand scheme of time, we have come at the end and everything before us is to be regarded as elders.

Continuing through, we come to "Parawhenuamea," written and performed by Aroha YatesSmith (2019b). Based on whakapapa and koorero, she describes the converging of Taane (deity of the forests) and Hinetuuparimaunga (deity of the mountains) to form puna (spring), bringing forth our deity Para-whenua-mea, embodied as our life-sustaining groundwaters. This is reiterated throughout the exhibition and reinforces women's role as uukaipoo (the source of sustenance). Natalie Robertson's short film "Puna Manawa Wai o Tikawa, Te Puna o Rangitauaki” (n.d.) (Te Rimu), depicts her ancestral spring, valued and protected as the source of life. Regan Balzer's artwork Toi tuu te Whenua, Whatu Ngarongaro te Tangata: People Come and Go but the Land Remains (n.d.) further supports Yates-Smith's koorero linking Parawhenuamea to Pelehonuamea of Hawai'i. We also see the visual embodiment in Hinetuparimaunga by Ripeka Terri Crawford in her production still from her te reo Maaori opera Goddess.

After the creation of our elemental deities come our human ancestors. "Hineahuone" (Tuffery 2020) tells of the creation of the first woman at Kurawaka. Beginning in te kore, the nothingness from which all life emerged in stages, this piece is told through a stunningly filmed sand art animation depicting how Hineahuone herself was shaped from the earth, reinforcing our connection to the land. The placement of this piece before the pito of the exhibition was particularly interesting. As a Maaori viewer, this reiterated for me Hineahuone as our first waahine, who was formed of the earth of our goddess Papatuaanuku, not born of the body. It would make sense that she would emerge before the pito with this logic.

"Laka" (Wilson-Hokowhitu 2020a) presents a very direct human connection with Laka, the Hawaiian ancestor of hula and the forest. Kanoelani Davis explains, as she makes a head lei from the fern palapalai, that it is the kinolau (one of many bodies) of Laka. She reiterates that caring for these kinolau is caring for ourselves, highlighting our dependence on our environment to survive. This care and concern for our environment is mirrored in Ka 'Opua à Hina (see Figure 3), by Maile Andrade (Kanaka Maoli), which fills the space near "Laka" from floor to ceiling. Guided by the mo 'olelo of Hina making such fine kapa (bark cloth), the clouds are attributed as her work. Ka 'Opua à Hina invites us to immerse ourselves in the finely beaten kapa sheets that dangle from the ceiling and sway as we walk by, their fragility emphasizing their beauty and mimicking the delicate nature of the world around us. 


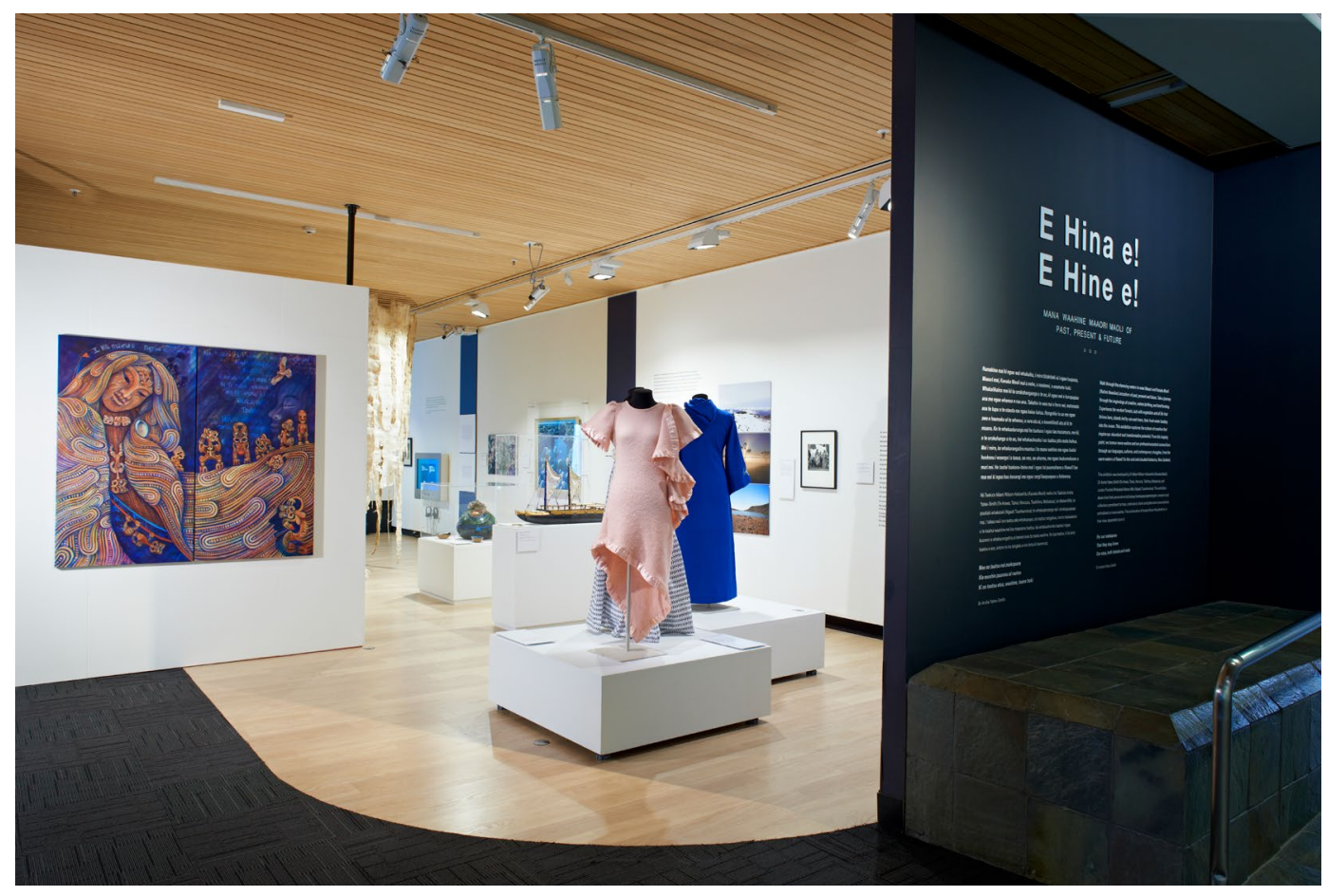

Figure 3. Installation view of E Hina e! E Hine e! Mana Waahine Maaori/Maoli of Past, Present and Future exhibition, Waikato Museum Te Whare Taonga o Waikato, 14 September 2019-10 October 2021. On the left is Toi tuu te Whenua, Whatu Ngarongaro te Tangata: People Come and Go but the Land Remains by Regan Balzer (Te Arawa, Ngaati Ranginui, Ngaati Kirihika, Ngaati Maniapoto). In the center background is Ka 'Opua a Hina by Maile Andrade (Kanaka Maoli).

"Moloka'i Nui a Hina" (Wilson-Hokowhitu 2020b) extends this interconnectivity. It opens with Maile Naehu and Kanoelani Davis (Kanaka Maoli) performing songs about Hina and her island child, Moloka'i. Their moolelo are loaded with lessons and understandings from antiquity. Maile explains how when Moloka'i was born, Hina needed to ensure her island child had everything it needed and so provided fresh water, the requirement for all life. It is no coincidence that our ancestors recognized the many forms of water as manifestations of the divine feminine. We are grown in the safety of water inside our mothers' wombs, the breaking of which signals our emergence from te po into te ao maarama (the world of light), in which we now reside.

Finally, we are brought into the modern day with "Moloka'i Nui a Hina-Creative Activation" (Wilson-Hokowhitu 2020c), which presents contemporary manifestations of these understandings in business, clothing design, slam poetry, and hip hop. For Kanoelani Davis, this means acknowledging the different forms of Hina across all time, and Hina's role in society and the world itself; she embeds her designs with the moolelo and messages of all Hina. Maile Naehu continues this, infusing poetry and hip hop with mólelo. Her goal is to build a new generation of "guardians" who are strongly grounded in their identity. Coupled with a global consciousness, Maile explains, these leaders can save the planet: "If we understood the kinolau of laka, then that way we understood that we need to take care of it as if we need to take care of ourselves" (Kanoelani Davis, quoted in "Laka," Wilson-Hokowhitu 2020a). Looking back through recent history, one does not have to look far to see modern manifestations of our waahine akua/atua in 
our contemporary women. Tuaiwa Rickard, Whina Cooper, Meri Mangakahia, Te Puea Hērangi, Pania Newton, and Pua Case, to name a few, have all led political movements to better the collective whole. As Maile Naehu knows, it is our descendants who will lead our people; therefore, it is important that they are grounded in their identity, understand the stories of their ancestors, and are globally conscious.

Further supporting this view, Natalie Robertson sees the potential that such reconnection may "offer models that could cultivate creative environmental revitalisation and restitution internationally" (Robertson n.d). As Regan Balzer's work states-Toi tuu te Whenua, Whatu Ngarongaro te Tangata: People Come and Go but the Land Remains-we have placed ourselves above everything else, deluded that we are superior to the elements and arrogant enough to believe we can control everything. However, if we are to continue to survive on this planet, we need to seriously reconsider our position in relation to the natural world and actively begin to repair the balance our ancestors knew was important so long ago. "Honor her and she will honor you" (Kanoelani Davis, quoted in "Moloka i Nui a Hina," Wilson-Hokowhitu 2020b).

From a Maaori viewer's perspective, E Hina e! E Hine e! is so thoroughly imbued with our Indigenous voice that the exhibition can, at times, feel like it is speaking to us privately-not in such a way as to exclude non-Indigenous peoples, but in acknowledgement that we are our own voice and that what we have to say is important. It is validating and empowering to have an exhibition that is for you, rather than about you. By reconnecting with koorero and moolelo of waahine atua/akua that debunk the constructed devalued position of waahine in Indigenous societies, it presents an opportunity to further decolonize our thinking and find inspiration in more accurate interpretations of our stories. We cannot do this with only half of our koorero. Adopting an Indigenous, more egalitarian mindset, informed by the complementary relationships of our atua/akua based on reciprocity, manaakitanga and kaitiakitanga, is a powerful step in the right direction.

He waahine, he whenua, i ngaro ai te tangata.

Without women and land, humanity is lost. ${ }^{8}$

Hollie Tawhiao,

Ngaati Tiipa

\section{NOTES}

1. Taken from vinyl lettering on the wall within the exhibition written by Dr. Nālani Wilson-Hokowhitu and Maree Mills (2019).

2. Overall, I have used double vowels in te reo Maaori (the Maaori language) to represent a long vowel sound, as it is the preference of the Waikato-Tainui iwi (tribe). However, some names, titles, and words in the Hawaiian language are shown with macrons.

3. Aotearoa New Zealand Maaori and Hawaiian Kanaka Maoli.

4. Triangles are important forms in te ao Maaori and hold many meanings depending on their context. This can include representing significant maunga (mountains); reproduction, as they resemble the uterus; and, more specifically to Waikato-Tainui, the niho taniwha (taniwha teeth). Taniwha are beings significant to Maaori, and the niho taniwha can be used to depict our chiefs and their whakapapa (genealogy) to the gods.

5. Koru are simplified fern fronds in the form of spirals. They are often used as symbols for creation, family, evolution and growth.

6. In April 2021, in response to requests for submissions for a definition of a "Museum," ICOM Aotearoa submitted to the Committee for Museum Definitions, Prospects and Potential that the new definition 
of museums should account for the notion that "Museums are not static but always move along a continuum with shifts in focus and practice, in response to changes in the dynamics of their communities where, over time, different voices may prevail" (ICOM Aotearoa New Zealand 2020). Dr. Nālani Wilson-Hokowhitu, Dr. Aroha Yates-Smith, and Maree Mills recognize the importance of this and have concentrated their research, knowledge, and commitment to amplifying mana waahine voices into this intricate and deeply nuanced exhibition.

7. Literally "people of the land."

8. This whakataukii (proverb) reinforces the Maaori belief that woman and land are synonymous with the continuation and preservation of humankind.

\section{REFERENCES}

Museums Aotearoa. 2021. "ICOM Definition of Museum - Aotearoa New Zealand", 11 April. https:// www.museumsaotearoa.org.nz/publications/repository/icom-definition-museum-aotearoa -new-zealand.

Mikaere, Ani. 2019. “Colonisation and the Imposition of Patriarchy: A Ngāti Raukawa Women's Perspective." In Mana Wahine Reader A Collection of Writings 1999-2019 Volume II, ed. Leonie Pihama, Linda Tuhiwai Smith, Naomi Simmonds, Joeliee Seed-Pihama, and Kirsten Gabel, 4-18. Hamilton, NZ: Te Kotahi Research Institute.

Noyes, Martha H. 2018. “The Celestial Roots of Mana." Time and Mind: The Journal of Archaeology, Consciousness and Culture 11 (4):371-384. https://doi.org/10.1080/1751696X.2018.1541129.

Ralston, Caroline. 1993. "Maori Women and the Politics of Tradition: What Roles and Power Did, Do, and Should Maori Women Exercise?” The Contemporary Pacific 5 (1): 23-44. http://www.jstor.org/ stable/23699869.

Robertson, Natalie. n.d. "Para-Whenua-Mea - Muddy-Soil-of-Mother-Earth: Personifications of Water in Te Ao Māori (the Māori world).” Openrepository AUT. https://openrepository.aut.ac.nz/bitstream/ handle/10292/13030/2019-10-06_CSD-Book-and-cover_small.pdf (accessed 29 May 2021).

Salmond, Anne. 2018. "Dame Anne Salmond: Neo-liberal Philosophy is Toxic and a Tragedy for Women.” Stuff, 19 September. https://www.stuff.co.nz/life-style/life/107210918/dame-anne -salmond-neoliberal-philosophy-is-toxic-and-a-tragedy-for-women.

Tuffery, Dawn. 2020. "Hineahuone." Video, 4:44. Uploaded 25 May. https://www.youtube.com/ watch? $\mathrm{v}=2$ S9x3IytKSs.

Wilson-Hokowhitu, Nālani. 2012. "He Pukoa Kani 'āina: Kanaka Maoli Approaches to Mo’okūauhau as Methodology." AlterNative: An International Journal of Indigenous Peoples 8 (2): 137-147.

Wilson-Hokowhitu, Nālani. 2020a. "Laka." Video, 3:37. Uploaded 25 May. https://www.youtube.com/ watch? $\mathrm{v}=\mathrm{OkAcKsb} 4 \mathrm{mCE}$.

Wilson-Hokowhitu, Nālani. 2020b. "Moloka'i Nui a Hina." Video, 5:02. Uploaded 25 May. https://www. youtube.com/watch?v=IGQqWSQlaK4.

Wilson-Hokowhitu, Nālani. 2020c. "Moloka i Nui a Hina - Creative Activation.” Video, 4:56. Uploaded 25 May. https://www.youtube.com/watch?v=hqRr3kI2UGo.

Wilson-Hokowhitu, Nālani. 2020d. "Póele and Kumulipo." Video, 3:51. Uploaded 25 May. https://www. youtube.com/watch? $\mathrm{v}=\mathrm{vEWbt7cfEQE}$.

Yates-Smith, Aroha. 2019a. "Reclaiming the Ancient Feminine in Māori Society: Kei Wareware i a Tātou Te Ükaipō!” In Mana Wahine Reader A Collection of Writings 1999-2019 Volume II, ed. Leonie Pihama, Linda Tuhiwai Smith, Naomi Simmonds, Joeliee Seed-Pihama, and Kirsten Gabel, 50-59. Hamilton, NZ: Te Kotahi Research Institute.

Yates-Smith, Aroha. 2019b. "Parawhenuamea." Video, 5:33. Uploaded 25 May. https://www.youtube. $\mathrm{com} /$ watch? $=$ u1QGRWZeNNI.

Yates-Smith, G. R. 2018. "Hine! e Hine! Rediscovering the Feminine in Maori Spirituality” (PhD diss., University of Waikato). 